\title{
PARADOXOS DO SINDICALISMO BRASILEIRO: A CUT E OS TRABALHADORES RURAIS*
}

\author{
Iram Jácome Rodrigues \\ Universidade de São Paulo (USP), São Paulo, SP - Brasil. \\ <ijrodrig@usp.br >>iramjrodrigues@gmail.com> \\ Mario Henrique Guedes Ladosky \\ Universidade Federal de Campinas Grande (UFCG), Campina Grande, PB - Brasil. \\ <mhladosky@gmail.com> \\ http://dx.doi.org/10.1590/ 0102-6445087-142/95
}

Este artigo tem como objetivo analisar a trajetória do sindicalismo rural no Brasil nas últimas três décadas, a partir de sua relação com a Central Única dos Trabalhadores (CUT) e da posição dessa central sindical no que tange aos trabalhadores rurais. Nesse sentido, aponta para o crescimento significativo do associativismo rural no interior da Central e procura explicar quais as razões que estariam levando à maior central sindical brasileira abrigar um contingente tão expressivo de associados do campo no conjunto de sua base sindicalizada. Para a consecução desses resultados, foram realizadas análises das resoluções de todos os congressos da CUT (Concuts) desde a sua fundação em 1983 até o último, realizado em 2012, num total de doze congressos nacionais. Além disso, foram utilizados dados quantitativos da PNAD/IBGE, do Ministério do Trabalho e Emprego (MTE) e da própria CUT sobre sindicalização. $\mathrm{O}$ texto analisa três questões que nos ajudam

\footnotetext{
Resultados parciais de projeto de pesquisa apoiado pelo CNPq. Agradecemos a Jonas Tomazi Bicev pelo tratamento estatístico dos dados quantitativos da Pesquisa Nacional por Amostra de Domicílio (PNAD) do Instituto Brasileiro de Geografia e Estatística (IBGE), que utilizamos na pesquisa.
} 
na compreensão desse processo: (1) Quais as razões do crescimento da sindicalização rural no âmbito do associativismo sindical brasileiro?; (2) Em que medida as políticas públicas nas últimas décadas contribuíram para esse processo? e (3) Quais as consequências para a ação sindical da CUT de uma expressiva presença de trabalhadores rurais em seu interior?

O texto se detém, ainda, na análise da relação entre base e direção no interior da CUT, a partir da reflexão sobre as implicações do significativo peso numérico dos trabalhadores do campo nessa instituição e a pequena representação destes nos organismos de representação da Central.

\section{Os rurais no período anterior ao surgimento da CUT}

Em março de 1963 foi sancionado pelo Presidente João Goulart o Estatuto do Trabalhador Rural, que reuniu a legislação para regular as relações trabalhistas no campo e o sindicalismo rural, seguido pela promulgação do Estatuto 88 da Terra, em março de 1964, que estabeleceu providências para políticas de "reforma agrária" e de "desenvolvimento rural”, regulamentando as condições de acesso à terra e os contratos de parceria e arrendamento. Esse documento passou a desenhar o perfil e os limites das demandas por reforma agrária conforme nos mostra Medeiros (2002, p. 12) e Picolotto (2009, p. 8; grifos no original), segundo o qual,

[...] o sindicalismo rural contribuiu de modo decisivo para enfraquecer os padrões tradicionais de dominação. Esta legislação reconheceu o trabalhador rural como uma "categoria profissional" (como parte do mundo do trabalho) e a existência de uma questão agrária, de interesses conflitantes dentro do que, até então, era tratado com um todo indivisível: a agricultura ou a classe rural.

De outra parte, a Confederação Nacional dos Trabalhadores na Agricultura (Contag) foi fundada em dezembro 
de 1963, no contexto do sindicalismo oficial, e teve em sua primeira diretoria eleita uma composição entre membros do Partido Comunista Brasileiro (PCB) e da Ação Popular (AP), de origem católica ligada à Teologia da Libertação, contra os setores conservadores da Igreja Católica. Sua constituição se fez sob a uniformização da identidade do trabalhador rural, sobrepondo-se à heterogeneidade das diversas situações de trabalho existentes, antes expressa sob a designação de camponês, trabalhador da lavoura, arrendatário, meeiro, parceiro, pequeno produtor, entre outros (Picolotto, 2009, p. 8).

No entanto, a ditadura civil-militar instaurada em março de 1964, utilizando as prerrogativas da Consolidação das Leis do Trabalho (CLT), interveio nas entidades sindicais oficiais, urbanas e rurais, depondo diretorias legitimamente eleitas e cassando dirigentes sindicais ${ }^{1}$. No lugar de Lyndolpho Silva, que havia sido eleito presidente em 1963, foi alçado à direção da Contag José Rotta, originário dos círculos católicos paulistas (Medeiros, 2014, p. 251). Nesse sentido, a estruturação da Contag se efetivou no período ditatorial em um contexto pouco favorável à mobilização contestatória e organização autônoma dos trabalhadores. Por força da conjuntura adversa, seu padrão de ação sindical teve de manter-se no limite da prudência e do respeito à legislação, adotando um tom de "reivindicação", no sentido de "pedido ao governo", e não no sentido de "direitos" (Picolotto, 2009, p. 7). Para Medeiros (2002, p. 14), diante da dura repressão do regime, o simples fato de invocar direitos caracterizava enfrentamento.

1 O Diário do Congresso Nacional, de 23 de abril de 1965, um ano, portanto, do golpe militar de 1964, traz exposição do então Ministro do Trabalho Arnaldo Sussekind indicando que "quarenta e quatro dirigentes sindicais tiveram seus direitos políticos suspensos e 761 entidades sindicais sofreram intervenção do Ministério do Trabalho [...] a maior porcentagem de intervenções ocorreu na região Nordeste $(42,32 \%)$, seguida logo de perto pela região Sudeste $(39,55 \%)$ )" (Souza Martins, 1979, pp. 99-100). 
Dessa forma, por meio da prática assistencialista prevista na estrutura sindical corporativa, o regime ditatorial civil-militar se utilizou dos sindicatos de trabalhadores rurais para implantar uma série de programas sociais que tinham por objetivo esvaziar o papel político e reivindicatório daquelas entidades e, ao mesmo tempo, desenvolver uma ação que diminuísse as tensões sociais no campo. Desse modo, foram criados o Fundo de Assistência e Previdência do Trabalhador Rural (FAPTR), posteriormente, em 1969, denominado Funrural; e o Decreto-lei no 276, de 1967, preconizado no Estatuto do Trabalhador Rural, relacionado à prestação de assistência médico-hospitalar aos trabalhadores rurais.

Em 1971, foi lançado o Programa de Assistência Rural (Prorural), ligado ao Funrural, que previa benefícios de aposentadoria e o aumento dos serviços de saúde até então concedidos aos trabalhadores rurais. Entre outras medidas, o Prorural previa a aposentadoria por velhice e por invalidez para trabalhadores rurais com mais de 70 anos de idade ${ }^{2}$, [à época] no valor de 1/2 salário mínimo; pensão, equivalente a $70 \%$ da aposentadoria, e auxílio funeral, para dependentes do beneficiário; serviços de saúde, incluindo assistência médico-cirúrgico-hospitalar e tratamento odontológico; serviço social em geral (Brumer, 2002, p. 56).

A implantação de tais serviços assistenciais por meio dos sindicatos esteve, contudo, longe de representar melhoria nas condições de vida e cidadania plena na área rural. Para Brumer (2002, p. 55),

[...] na prática, a cobertura previdenciária aos trabalhadores rurais [contida no Funrural] não se concretizou, pois os

2 Atualmente, é a partir de 60 anos. 
recursos (financeiros e administrativos) necessários à sua efetivação não foram previstos na legislação.

Assim, a despeito de os trabalhadores rurais terem conquistado o reconhecimento profissional, os sindicatos de trabalhadores rurais não tiveram como fazer valer seus direitos. Em um contexto altamente repressivo, nem os direitos formalizados em lei, nem as concepções de justiça que permitiram seu reconhecimento tiveram eficácia (Medeiros, 2002, p. 12).

Para Santos (1979, p. 116), no entanto,

[...] é, sobretudo, conectado à promoção da cidadania que o Funrural é, potencialmente, mais importante. Rompendo com o conceito de cidadania regulada e com a noção contratual de direitos sociais, o Funrural finca na existência do trabalho, contribuição social básica, a origem da pauta de direitos sociais igualmente básicos.

De modo geral, ao longo dos anos de 1970, a situação do trabalho no campo se transformou profundamente, propiciando o surgimento de novas questões e de novos atores políticos em relação ao período pré-1964.

A consolidação do capitalismo no campo, sob os auspícios do Estado, propiciou que grandes empresas nacionais e multinacionais do setor financeiro, comercial e industrial se constituíssem na área rural. A concentração de financiamento e de terras fez parte da nova política agrícola e agrária no país, tendo como consequência a ampliação do êxodo rural não apenas para as grandes metrópoles, mas também para as pequenas e médias cidades. Ao contrário do padrão anterior, os trabalhadores não mais morariam nas fazendas, mas no meio urbano circunvizinho. A mecanização da produção e o uso intensivo de produtos químicos em larga escala na plantação - denominada "Revolução 
Verde" - alteraram o processo de produção agrícola e a agroindústria, em muitas regiões substituiu os antigos latifúndios, assim como estendeu a fronteira agrícola em direção ao Centro-Oeste e à Amazônia, acompanhando grandes projetos de ocupação do território como a rodovia Transamazônica e a Belém-Brasília, da mesma forma que a busca de migrantes a longa distância para trabalhar temporariamente nos períodos mais intensivos da produção passou a fazer parte das estratégias de gestão da produção e do trabalho (Contag, 2003, p. 12).

Segundo Castro, Resende e Pires (2014, p. 35), a modernização da agropecuária nacional, proveniente do uso das inovações tecnológicas da chamada Revolução Verde, permitiu a ampliação do produto do setor agropecuário nacional e, assim, pôde colaborar para o desenvolvimento do setor industrial e urbano do país, não só lhe oferecendo alimentos, matérias-primas e mão de obra, mas também ser92 vindo de mercado para os seus produtos. Entretanto, essa estratégia de modernização da agropecuária nacional acentuou a heterogeneidade estrutural nesse setor econômico, pois reforçou a convivência, no mesmo espaço e tempo, de estruturas "modernas" e "atrasadas". Essa heterogeneidade estrutural, para os autores, foi fruto do ritmo e da forma diferenciada com que o progresso técnico penetrou nas estruturas tradicionais existentes na economia nacional.

A nova conjuntura que se abriu no meio rural nos anos de 1970 provocou a eclosão de novos tipos de conflito e, em decorrência desse processo, aos poucos foram se configurando novos interesses e novas formas de organização e luta, e, ao mesmo tempo, foram se constituindo novas identidades coletivas. Por essa razão, a Contag, que nos anos anteriores ao golpe civil-militar de 1964 aglutinou o conjunto das questões relativas à identidade de "trabalhador rural", vê a categoria política unificadora "implodida" e parte de sua representatividade solapada pela nova rea- 
lidade que emergiu das lutas agrárias a partir dos anos de 1980. Expressão mais evidente desses novos atores foi o surgimento do Movimento dos Trabalhadores Sem Terra (MST) em 1984, que se tornou a principal expressão pública da luta pela reforma agrária nos anos seguintes. Outros exemplos de novas demandas sociais e organização foram a luta dos seringueiros da Amazônia e a formação do Conselho Nacional dos Seringueiros (CNS), bem como a do Movimento dos Atingidos por Barragem (MAB), o Conselho da Articulação dos Povos Indígenas do Brasil (Capoib), e o Movimento Nacional dos Pescadores (Monape) (cf. Picolotto, 2009, p. 10; Medeiros, 2014, p. 263).

Paralelamente ao crescente peso das ocupações e acampamentos e, consequentemente, da presença política do MST e do revigoramento do debate sobre reforma agrária, já na década de 80 evidenciou-se um reordenamento do lugar político dos pequenos agricultores na sociedade, indicado não só pelo seu aparecimento na cena pública através de uma série de mobilizações, como pelo crescente peso que passaram a ganhar lideranças desse segmento no interior do sindicalismo rural [...]. Nesse contexto, surgiram diversas experiências de oposições sindicais em diferentes regiões do país. Elas passaram a conduzir mobilizações marcadas pela prática de trancamentos de estradas, portas de bancos e de órgãos públicos, como forma de dar visibilidade às suas demandas e pressionar o Estado a atendê-las. [...] Nas disputas políticas que recortavam o sindicalismo, os pequenos produtores progressivamente passaram a ocupar lugares de mais destaque, com as demandas de há muito existentes ganhando novo perfil através do seu reenquadramento dentro de um diagnóstico da situação agrária e agrícola do país, o que os levou a falar cada vez mais na necessidade de um "novo modelo de desenvolvimento", e não apenas na inversão de sinais das políticas públicas (Medeiros, 2002, pp. 20-21; grifos no original). 


\section{A CUT e a questão rural}

O sindicalismo rural tem forte presença na trajetória da CUT, e sua dinâmica acompanha as diferentes etapas que demarca a periodização da Central (cf. Rodrigues, 2011; Ladosky, 2009).

Em seu congresso de fundação, em agosto de 1983, do total dos 5.059 delegados que se fizeram presentes, 1.658 eram rurais $(44,7 \%)$ e representavam, naquele momento, 310 sindicatos $(38,9 \%)^{3}$ das 912 entidades que lá compareceram. A participação dos rurais nos três primeiros congressos da CUT $\left(1^{\circ}, 2^{\circ}\right.$ e $3^{\circ}$ Concut), respectivamente em 1984, 1986 e 1988, manteve-se no mesmo patamar elevado, em torno de um terço do total dos delegados, conferindo importante peso político ao setor dentro da Central. As resoluções desses três congressos continham uma pauta de demandas sociais com forte ênfase em uma reforma agrária "radical, ampla, massiva e imediata, sob o controle do conjunto dos trabalhadores".

94 Tais medidas deveriam ser acompanhadas por uma política agrícola que desse outra prioridade ao desenvolvimento agrário: financiamento a juros baixos e subsidiados; garantia do preço mínimo de produção fixado pelos trabalhadores rurais; garantia de armazenamento e estradas para escoar os produtos, meios de transporte e distribuição dos produtos agrícolas; assistência técnica gratuita que atendesse aos interesses dos trabalhadores rurais; comercialização direta entre produtores e consumidores, através de cooperativas de produção e consumo; e valorização da pequena produção; com garantia de preço justo ao pequeno produtor (cf. CUT, 1984, 1986, 1988).

Nos primeiros anos, a CUT ocupava um espaço político nos movimentos sociais que promoviam a luta pela terra, o

\footnotetext{
3 É relevante destacar que os dados da CUT, em 2013, no que tange ao número de entidades rurais filiadas à Central, apontam um percentual muito próximo daquele do congresso de 1983, ou seja, 38\%, conforme Tabela 5 adiante neste artigo.
} 
qual, depois, na década de 1990, passou a ter o MST como o principal protagonista. "Ocupações de terras ociosas e mal aproveitadas, sejam elas públicas ou particulares, de empresas nacionais ou multinacionais" e "realização de ocupações simultâneas, em vários locais num mesmo estado no País" foram temas aprovados no $2^{\circ}$ Concut, por exemplo.

Uma das explicações para a grande presença dos trabalhadores rurais nos quatro congressos iniciais da CUT, em 1983, 1984, 1986 e 1988, se deve, possivelmente, à forte influência da Igreja Católica no seio desses movimentos. Isso porque, no Brasil, no início dos anos de 1960, surgiu uma novidade, do ponto de vista organizativo, originada na Igreja Católica: as Comunidades Eclesiais de Base (CEBs). De acordo com Frei Betto (1981, pp. 16-17; grifos no original),

[...] as comunidades eclesiais de base (CEBs) são pequenos grupos organizados em torno da paróquia (urbana) ou da capela (rural), por iniciativa de leigos, padres ou bispos. As primeiras surgiram por volta de 1960, em Nísia Floresta, arquidiocese de Natal, segundo alguns pesquisadores, ou em Volta Redonda, segundo outros. De natureza religiosa e caráter pastoral, as CEBs podem ter dez, vinte ou cinquenta membros. Nas paróquias de periferia, as comunidades podem estar distribuídas em pequenos grupos ou formar um único grupão a que se dá o nome de comunidade eclesial de base. É o caso da zona rural, onde cem ou duzentas pessoas se reúnem numa capela aos domingos para celebrar o culto. São comunidades, porque reúnem pessoas que têm a mesma fé, pertencem à mesma Igreja e [habitam a] mesma região. Motivadas pela fé, essas pessoas vivem uma comum-união em torno de seus problemas de sobrevivência, de moradia, de lutas por melhores condições de vida e de anseios e esperanças libertadoras. São eclesiais, porque congregadas na Igreja, como núcleos básicos de comunidade de fé. São de base, porque integradas por 
pessoas que trabalham com as próprias mãos (classes populares): donas-de-casa, operários, subempregados, aposentados, jovens e empregados dos setores de serviços, na periferia urbana; na zona rural, assalariados agrícolas, posseiros, pequenos proprietários, arrendatários, peões e seus familiares. Há também comunidades indígenas.

Ainda, conforme o autor, existiriam no Brasil aproximadamente 80 mil CEBs, onde participariam cerca de 2 milhões de pessoas "crentes e oprimidas" (Frei Betto apud Rodrigues, 2011, pp. 65-66).

Assim, do ponto de vista organizativo, a CUT procurou ser a principal referência na construção da unidade dos diversos movimentos, seja através de uma ação radicalizada e conflitiva, seja pela amplitude de suas propostas que incluíam, entre outros, os atingidos por barragens, os seringueiros e outros povos da floresta, como a população indígena, segmentos quilombolas, meeiros, garimpeiros etc. $\mathrm{E}$ a influência do trabalho da Igreja Católica junto às comunidades rurais, bem como nas áreas urbanas, foi fundamental para essa reorganização do movimento sindical e diz muito da participação dos rurais no processo de associativismo sindical no Brasil ${ }^{4}$.

Ao mesmo tempo, a CUT colocava-se em disputa com o sindicalismo representado pela Confederação Nacional dos Trabalhadores na Agricultura (Contag), que, com a divisão do movimento sindical em 1983, seguiu a opção de fazer parte da Coordenação Nacional da Classe Trabalhadora (Conclat), organizada como a Central Geral dos Trabalhadores (CGT) após 1985. Assim, o setor rural da CUT teve aprovado no congresso de fundação, em 1983, a criação de uma secretaria específica para tratar da questão agrária, sendo substituída no $2^{\circ}$ Concut pela proposição de criar o

\footnotetext{
4 Sobre o surgimento da CUT em 1983 e sua relação com os rurais na década de 1980, bem como a atuação da Igreja Católica no sindicalismo rural, ver Favareto (2006, pp. 31-36).
} 
Departamento Nacional dos Trabalhadores Rurais (DNTR) e suas instâncias estaduais (DETRs).

Em relação aos assalariados rurais, a principal reivindicação nos anos de 1980 era a extensão dos direitos trabalhistas da CLT, sobretudo em relação à previdência, cujo teto dos rurais era meio salário mínimo; outra reivindicação referia-se ao combate à prática do trabalho análogo ao escravo no campo e maior fiscalização do Ministério do Trabalho para coibir tais práticas.

Desse modo, o segmento rural foi se firmando no interior do sindicalismo CUT. Em todas as direções executivas eleitas nos congressos houve uma representação do setor rural, embora sempre em proporção menor que sua representatividade no total dos delegados dos congressos.

A importante participação do sindicalismo rural na consolidação da CUT não foi obstáculo ao debate acerca da pertinência da representação sindical de pequenos proprietários, uma vez que, sob determinada interpretação do conceito de classe social, eles não seriam trabalhadores, mas empregadores. Para Novaes (1989), no entanto, a penetração do capitalismo no campo configurou uma heterogeneidade nas formas de exploração sobre o trabalho e, nesse sentido, afirma que

[...] construir a unidade política a partir da diversidade de situações de classe é o grande desafio para a organização dos trabalhadores no campo. Porém, para muitos, existem dúvidas, e até certo mal-estar, para incluir na "classe trabalhadora brasileira" pequenos produtores que lutam por preços dos produtos, por crédito agrícola, e que são donos de um "meio de produção" [...] Uma central sindical que se quer "classista" não poderia excluir pequenos produtores que, em sua luta, questionam a via ou o modelo que tem permitido a acumulação e o desenvolvimento do modo de produção capitalista no País (Novaes, 1989, p. 2). 
O final dos anos de 1980 assiste a uma mudança significativa da ação sindical da CUT, que se desenha com mais nitidez por ocasião do $3^{\circ}$ Concut, em 1988, e que teve implicações importantes na participação dos rurais. Em primeiro lugar, a modificação estatutária, que passaria a adotar o critério de número de sindicalizados para a eleição de delegados aos congressos da CUT e não mais o número de trabalhadores na base, como ocorria até então. Com isso, a representação da delegação de rurais teve forte retração nos congressos pós-1988. O $6^{\circ}$ Concut, em 1997, por exemplo, contou com apenas $9,5 \%$ de delegados rurais do total de participantes. Em segundo lugar, a aprovação das novas funções dos departamentos profissionais criados no $2^{\circ}$ Concut; estes deveriam se transformar em confederações dos respectivos ramos de atividade ou, quando possível, disputar as confederações da estrutura sindical oficial com as propostas da CUT. Por essa razão, no $4^{\circ}$ Concut, em 1991, pela 98 primeira vez a Central faz um balanço de sua organização entre os rurais, identificando grande crescimento no número de entidades filiadas e, com base no resultado positivo desse balanço, os delegados aprovaram, nesse congresso, a participação dos sindicatos rurais cutistas no Congresso da Contag que se realizaria em novembro daquele mesmo ano, defendendo a filiação da Contag à CUT.

A estratégia de participação dos trabalhadores rurais da CUT no $5^{\circ}$ congresso da Contag deverá ser no sentido de polarizar a nossa concepção sindical com as posições políticas que representam a velha estrutura.

O $4^{\circ}$ Concut reafirma a necessidade da unidade de ação, tanto nas lutas quanto na formação da chapa cutista, garantindo a unificação da CUT e do campo progressista [...] Portanto, esta não é uma tarefa somente dos trabalhadores rurais, mas de todas as instâncias da Central (CUT, 1991, p. 23). 
Assim, os mais de 1.500 delegados de todo o Brasil presentes no $4^{\circ}$ Concut, em São Paulo, definem as seguintes bandeiras de luta para serem levadas ao Congresso da Contag:

- Democratizar a Contag e todas as suas instâncias de deliberação, lutando pela aprovação de um novo estatuto que coloque o congresso como instância máxima de deliberação.

- Reafirmar o plano de luta dos trabalhadores rurais cutistas aprovado no $1^{\circ}$ Congresso do DNTR/CUT.

a) $\mathrm{O} 4^{\circ}$ Concut aprova que todos os sindicatos de trabalhadores rurais encaminhem a proposta de filiação da Contag à CUT.

- Garantir a constituição de uma chapa cutista, afirmando a proposta de estruturação sindical da CUT no campo (CUT, 1991, p. 23).

A aproximação entre CUT e Contag culminou com a filiação da Confederação à Central sindical em abril de 1995. Esse processo envolveu muito debate interno e polêmicas quanto à construção do ramo dos rurais na CUT. Uma parte das lideranças rurais entendia que se deveria persistir na consolidação do DNTR e não se dissolver na Contag, onde havia setores não cutistas. Venceu a proposta de extinguir o DNTR e suas instâncias estaduais, que ocorreu em novembro de 1995.

O $6^{\circ}$ Concut, em 1997, debateu a transformação da Contag em estrutura orgânica da CUT e não mais como confederação filiada. O debate se estendeu até o $7^{\circ}$ Concut, em 2000, mas não houve consenso sobre essa questão. Do mesmo modo, este congresso também discutiu a proposta de transformação dos sindicatos rurais de base municipal para base territorial, procurando articular nessa nova forma de organização um projeto de desenvolvimento ancorado na questão do território. 
Enquanto a CUT atuava no sentido de fortalecer seu vínculo com a Contag, através da organicidade à sua estrutura, esta, por outro lado, enfrentava questionamentos internos e o surgimento de novas entidades sindicais que buscavam representar frações específicas do setor rural. Assim, no final dos anos de 1980, em São Paulo, foi criada a Federação dos Empregados Rurais Assalariados do Estado de São Paulo (Feraesp), e, em 1997, a Federação dos Trabalhadores na Agricultura Familiar de Santa Catarina (Fetrafesc). Essas estruturas eram paralelas às federações oficiais existentes, filiadas à CUT, mas que tiveram recusadas as solicitações de filiação à Contag, no congresso de 1998, sob o argumento de que feriam o princípio da unicidade sindical. Anos mais tarde, em março de 2001, foi criada a Federação dos Trabalhadores na Agricultura Familiar (Fetraf Sul/CUT), aglutinando 178 sindicatos dos três estados da região, ampliando sua representação em nível nacio100 nal a partir de julho de 2004, com a criação da Federação dos Trabalhadores e Trabalhadoras na Agricultura Familiar do Brasil (Fetraf-Brasil/CUT). Desde então, a CUT passou a ter duas entidades nacionais de representação dos trabalhadores rurais: a Contag, buscando representar o conjunto dos trabalhadores rurais; e a Fetraf-Brasil, especificamente voltada aos trabalhadores da agricultura familiar - fato inaceitável para a Contag, que emitiu recado pela grande imprensa.

A Contag exige que a CUT defina a Confederação como a única que "representa os trabalhadores rurais e os agricultores familiares no interior da CUT”. E afirma: "É inaceitável que dirigentes da CUT, em vez de procurar unificar e fortalecer a organização dos trabalhadores filiados à CUT, procurem nos dividir para atender a interesses pessoais ou de grupos" (Folha de S.Paulo, 30 nov. 2005 apud Medeiros, 2014, p. 269). 
O resultado foi a desfiliação da Contag da CUT em 2009. Um dos fatores que concorreu para isso foi a disputa entre a CUT e a Central dos Trabalhadores e das Trabalhadoras do Brasil (CTB), uma central sindical formada em dezembro de 2007 a partir de uma cisão interna da CUT, quando ocorreu a saída em bloco dos membros da Corrente Sindical Classista (CSC). A razão para a formação da CTB, segundo Fernanda Forte (2013, p. 59) foi a busca de um espaço próprio dentro da estrutura sindical que se configurava após a promulgação da Lei $\mathrm{n}^{\circ} 11.648 / 2008$, de reconhecimento das centrais sindicais. Contudo, salienta a autora, a CTB não se constituiu em oposição à CUT. Seu estatuto rege princípio semelhante ao da CUT, e, segundo Wagner Gomes, da coordenação da CTB, "teremos uma relação de parceria prioritária com a CUT” (Forte, 2013, p. 59).

Embora a CUT seja a maior central sindical no conjunto dos setores econômicos conforme os critérios de aferição do Ministério do Trabalho e Emprego (MTE) em 2011 e $2012^{5}$, o peso da representação do sindicalismo rural na CTB é, proporcionalmente, maior que na $\mathrm{CUT}^{6}$. Em alguma medida, a desfiliação da Contag da CUT foi resultado de uma aliança entre membros ligados à CSC, lideranças da corrente Sindicalismo Socialista Brasileiro (SSB), ligada ao PSB (Partido Socialista Brasileiro), e sindicalistas independentes (Medeiros, 2014, p. 272). Foram 1.441 votos favoráveis à desfiliação e 1.109 votos contrários (cf. Fiori, 2009).

\footnotetext{
5 De acordo com os dados do MTE apresentados por Forte (2013, p. 51), a CUT foi, nesses anos, a maior central sindical, com cerca de $37 \%$ de representatividade, enquanto a CTB era a quarta maior central sindical, com $7,77 \%$ e $9,15 \%$ de representatividade, respectivamente, em 2011 e 2012.

6 De acordo com os dados do MTE em 2012, o peso dos rurais na CUT correspondia a $34 \%$ do total de entidades filiadas e 17,8\% da sindicalização total. Na CTB, os sindicatos rurais filiados representavam $48,2 \%$, e os sindicalizados rurais correspondiam a $23,7 \%$ do total. Embora a CTB fosse, naquele ano, a quarta maior central sindical do país, ela era, no setor rural, em termos proporcionais, a segunda maior central, atrás apenas da CUT.
} 
Assim, a Contag, desde então, não é filiada a qualquer central sindical. Mesmo após a desfiliação da CUT, inúmeros sindicatos e federações filiados à CUT permaneceram no quadro de entidades associadas à Confederação, e muitos dirigentes cutistas fazem parte do quadro de dirigentes da Contag atualmente, mantendo um quadro de equilíbrio político entre CUT e CTB na direção executiva nacional da Contag.

No interior do sindicalismo rural da CUT, a desfiliação da Contag propiciou a retomada da discussão sobre uma estratégia política cutista para os rurais, debate interrompido quando a CUT decidiu participar da Contag, que resultou na filiação à Central e na extinção do DNTR. Por isso, o acirramento das disputas entre "contagueanos" e "fetrafeanos" em anos recentes, que também reflete o protagonismo do segmento da agricultura familiar em meio à diversidade de setores que conformam o universo do trabalho rural, como já assinalado. E o destaque conquistado pelo 102 segmento da agricultura familiar está relacionado ao incremento de políticas públicas voltadas a esse segmento desde o governo FHC e, com a enorme ampliação dessas políticas desde a posse do Presidente Lula em 2003 (Medeiros, 2014, pp. 275-76).

O debate sobre a questão rural na CUT mantém, nos anos de 1990, a mesma temática, mas não a mesma abordagem. Reforma agrária, reforma agrícola, combate à violência contra lideranças rurais, entre outras, permanecem na pauta reivindicatória. No entanto, para além do debate mais ideológico, no que diz respeito à reforma agrária, reforma agrícola etc., outra questão é introduzida na agenda: a dimensão técnica para que possam ser viabilizadas essas demandas. No $5^{\circ}$ Concut, em 1994, por exemplo, pela primeira vez a CUT reconhece que há uma "revolução tecnológica” no campo, com a adoção de engenharia genética e altos investimentos capitalistas do agronegócio que contribui para o balanço de pagamentos do país. Em termos com- 
parativos, o $5^{\circ}$ Concut expressa uma visão mais sofisticada do que os textos deixavam implícitos nas resoluções anteriores, em que se considerava o rural simplesmente como o "atraso" do latifúndio tradicional a ser combatido com a reforma agrária. Não se abre mão daquele diagnóstico, mas a Central começa a reconhecer que o quadro é bem mais complexo do que o anteriormente apresentado (CUT, 1994, pp. 17-20).

No mesmo diapasão, desenvolve-se o projeto CUT/ Contag entre 1998 e 1999, realizando uma extensa pesquisa, que terminou por identificar 26 dinâmicas diferenciadas de desenvolvimento no meio rural brasileiro, cada uma demandando formas específicas de organização sindical e a necessidade de uma flexibilização da estrutura sindical no campo, de modo a permitir que os trabalhadores pudessem se organizar mais adequadamente para o encaminhamento de suas lutas.

A partir desse diagnóstico e de um acúmulo político no interior do sindicalismo rural cutista, relacionado às propostas aprovadas desde o congresso de fundação da Central, em 1983, o $7^{\circ}$ Concut, em 2000, consolidou essa trajetória do sindicalismo CUT no que tange ao meio rural, com a aprovação do Projeto Alternativo de Desenvolvimento Rural Sustentável (PADRS).

É importante ressaltar que, de acordo com dados da CUT, a delegação de sindicalistas rurais ficou com uma média de $17,1 \%$ dentre os presentes no $9^{\circ}, 10^{\circ}$ e $11^{\circ}$ Concut, realizados, respectivamente, em 2006, 2009 e 2012.

Observando os documentos com as resoluções congressuais, é significativa a perda de espaço da temática rural no conjunto das análises e proposições da CUT: no $8^{\circ}$ Concut, em 2003, foram dedicadas aproximadamente nove páginas, enquanto nos congressos seguintes essas páginas reduziram-se para pouco menos de duas, em média. Não se trata de uma questão meramente quantitativa. Esse congresso 
ocorreu no primeiro ano do governo Lula e as resoluções refletem o contexto daquele momento. A CUT reafirma a necessidade da reforma agrária, mas esta deixa de ser "apenas uma bandeira reivindicatória" (tal como aparecia nos congressos anteriores) e ganha um estatuto de maior complexidade na análise e proposição ao incorporar para além das "questões político-ideológicas" temas estritamente "técnicos", trazendo à agenda sindical aspectos relacionados ao papel do Judiciário e do Legislativo na efetivação das referidas medidas, bem como a questão tributária, como o Imposto Territorial Rural (ITR), entre outros; no que se refere ao orçamento público: Plano Plurianual (PPA), Lei de Diretrizes Orçamentárias (LDO), Lei Orçamentária Anual (LOA) e políticas públicas para a sua implantação. No documento da CUT, a reforma agrária deixa de ser mera demanda ao Executivo e passa a ser uma questão para o Estado, em uma "visão" compatível com uma interpreta-

104 ção corrente no interior da CUT, à época, de que o governo Lula seria "um governo em disputa" e que o movimento sindical "deveria pressionar outros atores do aparelho do Estado" com o objetivo de viabilizar as demandas dos movimentos sociais etc. A citação de leis e resoluções de conselhos e outros órgãos seria sintomática dessa "visão ampliada" sobre a reforma agrária.

Da mesma forma, a agricultura familiar também recebeu no $8^{\circ}$ Concut uma análise apropriada para quem tem a preocupação de ser propositivo e encontrava-se em um contexto de viabilidade política real para a implantação de suas demandas. Ao mesmo tempo que se colocava com uma responsabilidade política em fazer proposição factível, a CUT manifestava também a expectativa de que o novo governo atenderia à sua demanda.

A vitória das forças populares com a eleição de Lula deve agora iniciar um processo de luta pelo rompimento com 
essa história vergonhosa de injustiça social. Não podemos perder essa oportunidade histórica (CUT, 2003, p. 44).

No entanto, se o financiamento da agricultura familiar tomou um grande impulso a partir do governo Lula e foi fator de relevante sucesso em sua política social voltada aos trabalhadores rurais, o mesmo não se pode dizer da reforma agrária, uma bandeira histórica defendida pela CUT.

A aprovação do II Plano Nacional de Reforma Agrária (PNRA), em 2003, estabeleceu como meta o assentamento de 400 mil famílias, financiamento da aquisição de terras para 130 mil famílias e a regularização das terras de 500 mil famílias no período 2003-2006. Segundo Fernandes (2013, p. 195), foram cumpridos $37 \%$ das metas do II PNRA para o primeiro mandato do Presidente Lula, e, no segundo mandato, "a reforma agrária perdeu força e os números caíram pela metade”. Para Ariovaldo Umbelino, em entrevista a Ramos (2011), "o governo [Lula] nunca fez uma ação realmente profunda de Reforma Agrária”. A frustração pela ausência de uma reforma agrária no país durante o governo Lula talvez seja um fator explicativo de por que a questão rural teve seu espaço diminuído a partir do $9^{\circ}$ Concut, em 2006, e nos dois congressos seguintes, em 2009 e 2012.

As resoluções do $9^{\circ}$ Concut deram mais ênfase à estratégia política de consolidar a sua organização no campo do que, mais propriamente, às demandas do setor rural. $\mathrm{O}$ mesmo se passa no $10^{\circ}$ Concut, em 2009, quando a Contag estava em vias de se desfiliar da CUT e já se vislumbrava um possível acirramento da disputa sindical no meio rural. Apenas o $11^{\circ}$ Concut, em 2012, volta a dedicar uma reflexão (mais "politizada" e menos "técnica") sobre a situação dos trabalhadores rurais e resgata reivindicações que haviam sido relegadas nos congressos anteriores, como a reforma agrária, o apoio à agricultura familiar, e uma política para os assalariados rurais. 


\section{Políticas públicas voltadas à agricultura familiar}

Desde o surgimento da CUT, a partir das resoluções de seus congressos, plenárias e/ou encontros, conforme analisado neste artigo, há o reconhecimento da heterogeneidade de situações de trabalho do setor rural, que se reflete em uma diversidade de interesses e demandas específicas. Tal situação é reiteradamente debatida a cada congresso em que a CUT aprova um plano de lutas bastante amplo - em muitos aspectos funcionam como meras declarações ${ }^{7}$, mas que, no plano mais geral, têm o sentido de orientar a ação de suas entidades de base, normalmente, apoiado pelo slogan "construir a unidade na diversidade".

Nesse sentido, as proposições da CUT, desde a sua fundação, em defesa de uma política agrícola que garantisse maior facilidade de acesso a crédito subsidiado ou a juros baixos, e outras demandas voltadas à assistência técnica, armazenamento, transporte e garantia de preços para a 106 comercialização de produtos, começou a se tornar realidade quando foi criado, em 1994, durante o governo Itamar Franco, o Programa de Valorização da Pequena Produção Rural (Provap), sucedido pelo Programa Nacional de Fortalecimento da Agricultura Familiar (Pronaf), criado em $1995^{8}$, no governo $\mathrm{FHC}$, destinado especificamente ao financiamento desse segmento de trabalhadores rurais, baseado em critérios historicamente defendidos pelo movimento sindical (Medeiros, 2014, p. 265).

A formatação do Pronaf incluiu a criação de conselhos nacional, estaduais e municipais de desenvolvimento, onde se previa a participação dos agricultores na gestão das

\footnotetext{
7 Para Rodrigues (1990, p. 91), as palavras de ordem, as declarações nos congressos etc. "se destinam a 'conscientizar', 'politizar' a massa de trabalhadores e, de modo mais difuso, fazer pressão sobre o conjunto do sistema político". Elas fariam parte, pois, de um "vasto campo das ações expressivas que servem para a construção da identidade grupal, para reforçar a coesão interna. Não têm, na realidade, um sentido instrumental, mas uma intenção pedagógica".

8 Resolução do Banco Central do Brasil, em agosto de 1995.
} 
seguintes linhas que constam do Programa: elaboração e negociação de políticas para a agricultura familiar, infraestrutura e serviços para os municípios, capacitação e formação profissional, e financiamento rural. No $6^{\circ}$ Concut, em 1997, a resolução exalta a criação do Pronaf como "uma das grandes conquistas do sindicalismo rural no último período" (grifos nossos). As críticas, então formuladas pelos delegados ao congresso, se relacionam aos limites do alcance do programa, em face da grande demanda.

O montante de recursos é extremamente insuficiente para cobrir a demanda da agricultura familiar brasileira. Os parcos recursos, hoje disponíveis, são destinados aos setores da agricultura familiar [já] mais estruturados. Por fim, mesmo estes agricultores situados nas categorias "consolidados" e "em transição", têm tido grandes dificuldades em ter acesso ao crédito, sobretudo em função das exigências colocadas, das altas taxas de juros e da burocracia do sistema financeiro na liberação dos recursos. As propostas de política agrícola a serem defendidas pela CUT devem se orientar [pelo] aprofundamento da implantação do Pronaf, com ampliação do montante de recursos e de municípios atingidos e a instituição de mecanismos específicos para os segmentos mais marginalizados hoje não atingidos pelo programa (CUT, 1997, p. 28).

No $7^{\circ}$ Concut, em 2000, a resolução reitera que:

\section{[...] as ações desenvolvidas pelo sindicalismo devem-se voltar} principalmente para a consolidação, expansão e aperfeiçoamento de ações como, por exemplo, o Pronaf e a política de assentamentos, formando com várias outras políticas sociais (educação, saúde, lazer e cultura etc.) uma rede voltada ao fortalecimento da família rural. (CUT, 2000, p. 25; grifos nossos). 
Em alguma medida, a consecução, ainda que parcial desses objetivos, só foi alcançada com a ascensão de Lula à presidência da República. Segundo dados do Ministério do Desenvolvimento Agrário (MDA), os valores disponibilizados pelo Pronaf se elevaram de $\mathrm{R} \$ 4,5$ bilhões na safra 2002/2003 para $\mathrm{R} \$ 21$ bilhões na safra 2013/2014, com a expectativa de atingir $\mathrm{R} \$ 24,1$ bilhões na safra 2014/2015 (ver Gráfico 1). O dado mais importante nesse gráfico se refere ao crescimento contínuo dos recursos aportados à agricultura familiar pelo Pronaf desde 2002.

\section{Gráfico 1}

Evolução do Pronaf no Plano Safra da Agricultura Familiar (valores em bilhões)

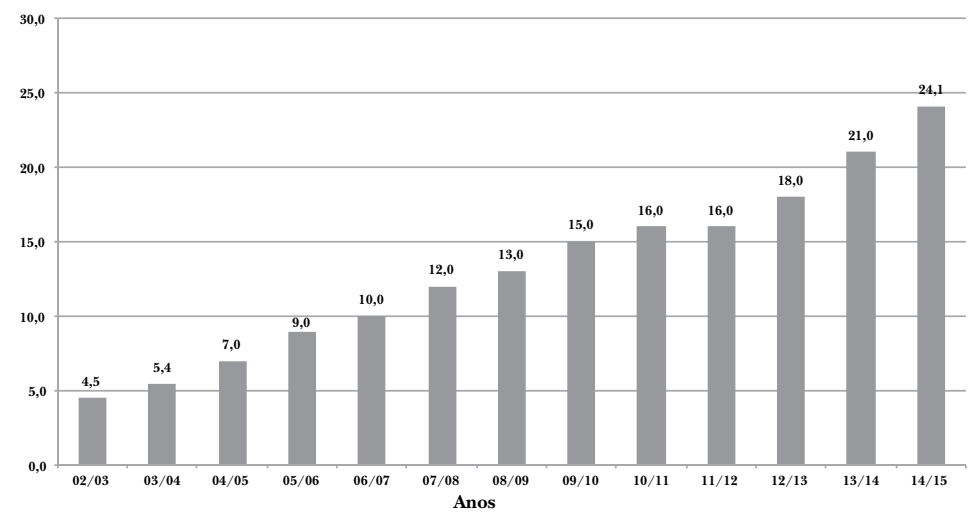

Fonte: MDA 2014. Elaboração própria.

Castro, Resende e Pires (2014, p. 16) utilizam a mesma base de dados divulgada pelo MDA, para o período 20002010, indicando a distribuição do volume de recursos contratados pelas regiões do país. Nesse sentido, a partir dos dados apresentados pelos autores, obtém-se o crescimento do volume de recursos contratados em cada região no mesmo período. Chama a atenção o volume disponibilizado para 
a Região Sul, quase $50 \%$ do total. Esse fato se deve, certamente, à tradição da agricultura familiar nos três estados que a compõem (Paraná, Santa Catarina e Rio Grande do Sul) e, ao mesmo tempo, à tradição de organização e mobilização desse setor nas demandas por seus interesses. As outras duas regiões com uma participação significativa no cômputo desses recursos são Sudeste e Nordeste com, respectivamente, $20,2 \%$ e $18,8 \%$. Nesse aspecto, muito abaixo daqueles valores alocados à Região Sul, conforme o Gráfico 2.

\section{Gráfico 2}

Distribuição no volume de recursos do Pronaf por região (2000-2010)

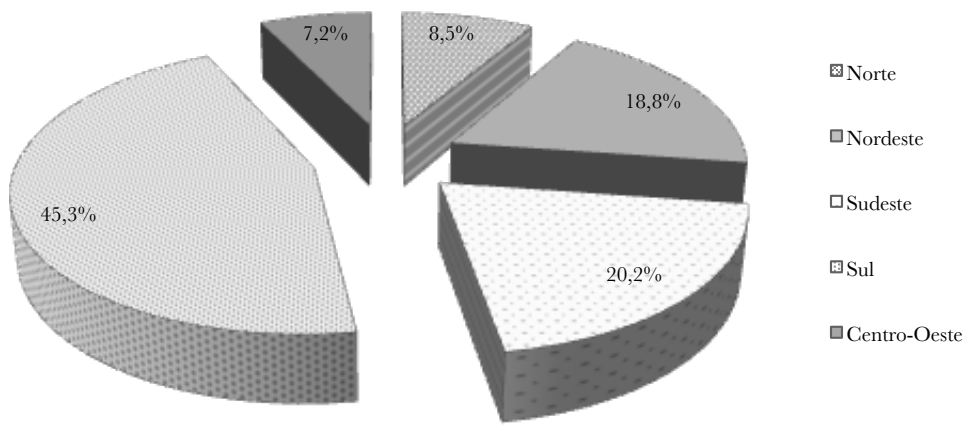

Fonte: MDA (Castro et al., 2014, p. 16). Elaboração própria.

Embora a criação do Pronaf seja de agosto de 1995, somente onze anos depois, em julho de 2006, seria promulgada uma legislação para normatizar e estabelecer diretrizes para a formulação de uma política nacional para a agricultura familiar. A Lei $\mathrm{n}^{\circ}$ 11.326/2006, artigo 3, conceitua a agricultura familiar do seguinte modo:

Para os efeitos desta lei, considera-se agricultor familiar e empreendedor familiar rural aquele que pratica 
atividades no meio rural, atendendo, simultaneamente, aos seguintes requisitos: I - não detenha, a qualquer título, área maior do que 4 (quatro) módulos fiscais; II - utilize predominantemente mão de obra da própria família nas atividades econômicas do seu estabelecimento ou empreendimento; III - tenha percentual mínimo da renda familiar originada de atividades econômicas do seu estabelecimento ou empreendimento, na forma definida pelo Poder Executivo; IV - dirija seu estabelecimento ou empreendimento com sua família (Brasil, 2006).

De outra parte, a obtenção dos recursos do Pronaf requer que os produtores familiares apresentem a Declaração de Aptidão ao Pronaf (DAP), emitida pelas instituições e órgãos oficiais autorizados, entre eles os sindicatos de trabalhadores rurais.

A política agrícola nos governos Lula e Dilma não se limi110 tou à expansão do crédito pelo Pronaf ${ }^{9}$ em suas diversas modalidades: Pronaf Mulher, Pronaf Jovem, Pronaf Semiárido, Pronaf Agroindústria Familiar, Pronaf Florestal, entre outros. Há trinta outros programas que são de responsabilidade da Secretaria da Agricultura Familiar do Ministério do Desenvolvimento Agrário. Alguns deles, como o Programa de Aquisição de Alimentos (PAA) e o Programa Nacional de Alimentação Escolar (PNAE) fazem parte do escopo de geração de renda e agregação de valor aos produtos. Há programas de assistência técnica e extensão rural; e de financiamento e proteção da produção, onde está alocado tanto o Pronaf como o Programa de Garantia de Preços para a Agricultura Familiar (PGPAF), o Programa Garantia-Safra e o programa Mais Alimentos, entre outros (MDA, 2014a, 2014b, várias datas).

\footnotetext{
9 Há dezesseis linhas de financiamento do Pronaf, voltadas para diversos grupos, para tipos de produção específicos, e para regiões. Disponível em: <http://www. contag.org.br/indexdet2.php? modulo=portal\&acao=interna2\&codpag=301\&cap=1 $\&$ nw=1\&ap=1>. Acesso em: 24 jun. 2015.
} 
Além disso, outra política social que aproxima as entidades sindicais rurais dos trabalhadores é a aposentadoria, cujo direito só foi reconhecido após a promulgação da Constituição de 1988. A regulamentação desse direito pela Lei $\mathrm{n}^{\circ} 8.213 / 1991$ deixou vago o entendimento acerca da comprovação material do exercício daquela atividade econômica para ter o benefício. Segundo o Ministério da Previdência Social (MPS), a solicitação da aposentadoria requer a apresentação de uma série de documentos de comprovação da atividade rural, entre eles uma declaração do sindicato dos trabalhadores rurais ou sindicato de pescadores ou colônia de pescadores, desde que acompanhada por documentos nos quais conste a atividade a ser comprovada, podendo ser, entre outros, a contribuição social ao sindicato de trabalhadores rurais, a Declaração Anual de Produtor (DAP), ou o recibo de pagamento de contribuição confederativa, por exemplo (MPS, 2014).

Estes dois instrumentos de política pública, no âmbito rural, o Pronaf e a questão da aposentadoria, no limite têm os sindicatos e/ou associações de trabalhadores como interlocutores e/ou partícipes, por desempenharem o papel de indicar, referendar, apoiar o agricultor familiar que demanda por crédito para sua lavoura com juros subsidiados ou que reivindica sua aposentadoria. Para esse setor, os aspectos anteriormente assinalados são vistos como "conquistas" de seus movimentos e de organização e, nesse sentido, têm uma capacidade crescente de agregação de um número cada vez maior de pequenos agricultores familiares às fileiras do associativismo rural.

Assim, observa-se que o Pronaf e a aposentadoria do trabalhador rural têm sua origem antes do governo Lula. No entanto, especificamente com relação ao Pronaf, foi a partir de 2003 que ocorreu um incremento significativo para esse programa, seja com relação ao volume de recursos, seja no que tange aos percentuais de execução (cf. Castro, Resende 
e Pires, 2014). De outra parte, ocorreu nesse período uma expressiva melhoria de renda dos aposentados mais pobres em decorrência da política de valorização do salário mínimo (o fator previdenciário recai sobre as aposentadorias de valor mais alto, de trabalhadores celetistas).

Tais políticas foram levadas adiante, em alguma medida, pela ação reivindicatória do movimento sindical e por políticas governamentais que, nos últimos anos, têm privilegiado, com mais ênfase, a inclusão social. E esse movimento mais geral favoreceu uma dinâmica de ampliação das atividades sindicais e a aproximação com os trabalhadores em busca dos referidos benefícios. Com isso, os sindicatos rurais se tornaram, em parte, uma expressão da capilaridade desse processo, ao mediar o acesso dos trabalhadores às políticas públicas. Isso não significa, necessariamente, uma acomodação na ação sindical, uma vez que tais benefícios (política de financiamento agrícola e direito à aposentadoria) foram 112 considerados conquistas pelos trabalhadores. E, talvez, por essa razão, a sua regulamentação trouxe importantes implicações para o nível de sindicalização no campo, como se verá na seção seguinte.

\section{Tendências atuais da sindicalização no Brasil e a temática rural}

Esta parte do artigo trata da questão do associativismo sindical no Brasil de 1992 até 2013, em anos selecionados (dados da Pnad/IBGE), e, no que se refere ao período mais recente (anos de 2012 e 2013), também são utilizados dados do Ministério do Trabalho e Emprego (MTE) e da CUT. É importante ressaltar que essas informações não têm a precisão que, muitas vezes, esperamos delas. Nesse sentido, devem ser lidas como tendências do fenômeno que estamos analisando: a importância cada vez maior do rural no âmbito do sindicalismo brasileiro e, em especial, no interior da maior central sindical brasileira. Além disso, entre os 
setores não urbanos, ganha destaque a participação organizada daquele contingente não assalariado entre os trabalhadores rurais, formado, em grande medida, pelos produtores e/ou agricultores familiares ${ }^{10}$.

Os dados da Pnad/IBGE 2013 dão conta que a População Ocupada Adulta (POA) (maiores de 18 anos) representava um total de 93.532.075 pessoas. Deste conjunto, $16 \%$ eram sindicalizados, o que perfazia, em números absolutos, 15.421.153. O que os indicadores mostram é um processo de queda no índice de sindicalização. Apenas para exemplificar: na série histórica dos anos selecionados no período 1992-2013, observamos, no início do período (1992), um índice de sindicalização da ordem de 19\%; já, ao final do período (2013), este patamar cai para $16 \%^{11}$.

No que tange à sindicalização por região, no período, conforme se vê no Gráfico 3, na comparação dos anos selecionados de 1992 a 2013, verificamos que a Região Sul, que era, de longe, a região mais sindicalizada, caiu de $26 \%$ para $19 \%$. A Região Sudeste também diminuiu o seu percentual de sindicalizados: de $18 \%$ para $14 \%$. Os dados referentes às regiões Norte e Centro-Oeste se mantiveram relativamente constantes no período, apesar da oscilação negativa da taxa de sindicalização, em 2002, na Região Norte. O fato mais surpreendente, no entanto, é o crescimento da sindicalização no Nordeste: única região do país onde ocorreu crescimento do associativismo sindical. Neste caso, a taxa foi de $16 \%$ para $20 \%$. Uma das hipóteses para a compreensão desse fenômeno, possivelmente, se deve, de um lado, ao crescimento das atividades pro-

\footnotetext{
${ }^{10}$ Para uma análise mais ampla sobre os dados da Pnad/IBGE e as novas configurações do sindicalismo brasileiro, ver Rodrigues e Ramalho (2014). Para uma discussão mais específica do sindicalismo dos agricultores familiares, em especial na Região Sul do Brasil, ver, entre outros, Picolotto (2009, 2011, 2013 e 2014) e Favareto (2006).

${ }^{11}$ Sobre as taxas de sindicalização no Brasil, ver, entre outros, Cardoso (1999, pp. 81-106; 2013, pp. 187-236; e 2014, pp. 122-25) e Pichler (2011, pp. 37-46).
} 
dutivas na região, principalmente, nos últimos dez anos, e, de outro, ao papel desempenhado pelo setor rural na composição desses percentuais.

É, nesse sentido, que a Tabela 1 ilustra muito bem esse fenômeno. Quando se separa o Brasil sindicalizado entre as áreas rurais e urbanas, entre 1992 e 2013 observa-se, na População Ocupada Adulta, diminuição do associativismo no setor urbano: de 23\% de sindicalizados em 1992 para $15 \%$ em 2013, ou seja, oito pontos a menos. De outra parte, inversamente, há um crescimento, no mesmo período, nas áreas rurais de sete pontos. Foi de 17\% em 1992 para $24 \%$ em 2013. Poderíamos dizer que é, no mínimo, paradoxal o crescimento da sindicalização rural nesse patamar. Além disso, é importante ressaltar, ainda, como mostra a Tabela 1, que a sindicalização rural chegou a 25\% em 2004 e $26 \%$ em 2008, caindo para $24 \%$ em 2012 e mantendo este índice em 2013.

\section{Gráfico 3}

Taxa de sindicalização de POA por região (Brasil)

(em \%)

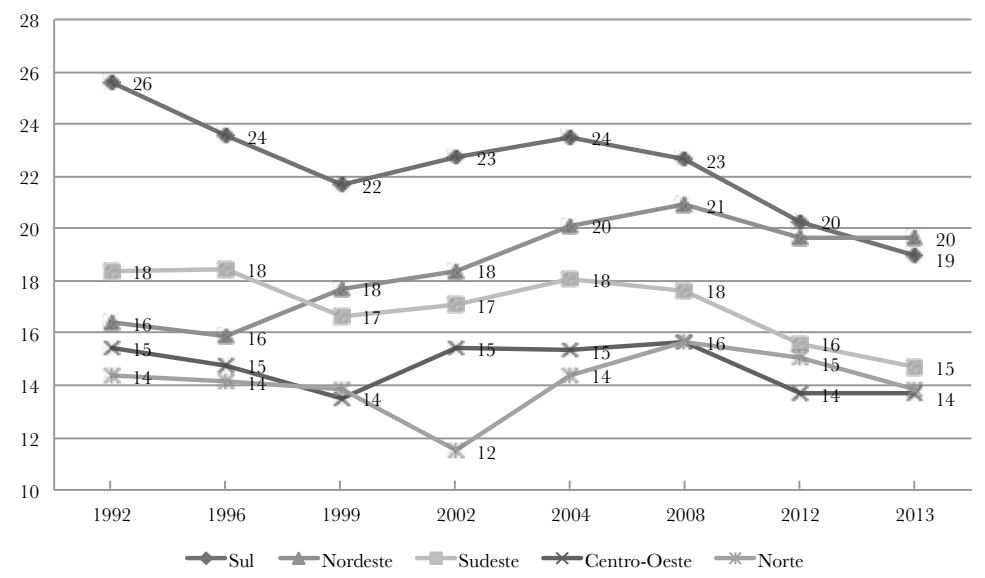

Fonte: Pnad/IBGE. Anos selecionados. Elaboração própria. 


\section{Tabela 1}

Sindicalização nas áreas urbanas e rurais de POA Adulta (Brasil)

\begin{tabular}{|c|c|c|c|c|c|c|c|c|}
\cline { 2 - 9 } \multicolumn{1}{c|}{} & 1992 & 1996 & 1999 & 2002 & 2004 & 2008 & 2012 & 2013 \\
\hline $\begin{array}{c}\text { Áreas } \\
\text { urbanas }\end{array}$ & $\begin{array}{c}8.449 .366 \\
(23 \%)\end{array}$ & $\begin{array}{c}8.847 .573 \\
(23 \%)\end{array}$ & $\begin{array}{c}8.714 .068 \\
(20 \%)\end{array}$ & $\begin{array}{c}10.258 .080 \\
(21 \%)\end{array}$ & $\begin{array}{c}11.455 .842 \\
(22 \%)\end{array}$ & $\begin{array}{c}12.861 .234 \\
(21 \%)\end{array}$ & $\begin{array}{c}12.329 .622 \\
(19 \%)\end{array}$ & $\begin{array}{c}11.991 .421 \\
(15 \%)\end{array}$ \\
\hline $\begin{array}{c}\text { Áreas } \\
\text { rurais }\end{array}$ & $\begin{array}{c}2.335 .750 \\
(17 \%)\end{array}$ & $\begin{array}{c}2.315 .983 \\
(17 \%)\end{array}$ & $\begin{array}{c}2.713 .175 \\
(19 \%)\end{array}$ & $\begin{array}{c}3.000 .942 \\
(23 \%)\end{array}$ & $\begin{array}{c}3.651 .656 \\
(25 \%)\end{array}$ & $\begin{array}{c}3.865 .445 \\
(26 \%)\end{array}$ & $\begin{array}{c}3.339 .717 \\
(24 \%)\end{array}$ & $\begin{array}{c}3.429 .732 \\
(24 \%)\end{array}$ \\
\hline Total & $\begin{array}{c}10.785 .116 \\
(19 \%)\end{array}$ & $\begin{array}{c}11.163 .556 \\
(18 \%)\end{array}$ & $\begin{array}{c}11.427 .243 \\
(17 \%)\end{array}$ & $\begin{array}{c}13.259 .022 \\
(18,0 \%)\end{array}$ & $\begin{array}{c}15.107 .498 \\
(19 \%)\end{array}$ & $\begin{array}{c}16.726 .679 \\
(19 \%)\end{array}$ & $\begin{array}{c}15.669 .339 \\
(17 \%)\end{array}$ & $\begin{array}{c}15.421 .153 \\
(16 \%)\end{array}$ \\
\hline
\end{tabular}

Fonte: Pnad/IBGE. Anos selecionados. Elaboração própria.

Já a Tabela 2 mostra a sindicalização da População Ocupada Adulta rural, segundo a condição de assalariamento. E aqui, mais uma vez, um dado aparentemente paradoxal: quando cotejamos o percentual de assalariados rurais sindicalizados com aqueles não assalariados rurais, em 2013, de acordo com os dados da Pnad/IBGE, encontramos $15 \%$ da mão de obra assalariada rural sindicalizada e, entre os trabalhadores rurais não assalariados, o percentual alcança 30\%. É interessante notar, que, em 2012, o percentual dos não assalariados era ainda maior: $31 \%$. Conforme Rodrigues e Ramalho (2014, pp. 394-95; grifos no original), no período 1992-2012,

[...] a taxa de sindicalização dos assalariados agrícolas se mantém estável, praticamente, por todo o período [...] em torno de $15 \%$. Ao mesmo tempo, a densidade sindical dos não assalariados agrícolas, que em 1992 já era maior que a dos assalariados (18\%), atinge em 2012 31\%.

O que a Tabela 2, assim como os outros dados, chama a atenção é para o fenômeno da sindicalização rural não assalariada, fundamentalmente entre os agricultores familiares, conforme estudos de Picolotto (2009) já citados, para 


\section{Tabela 2}

Sindicalização rural segundo condição de assalariamento (2013)

\begin{tabular}{|c|c|c|c|}
\cline { 2 - 4 } \multicolumn{1}{c|}{} & Sindicalizados & $\begin{array}{c}\text { Não } \\
\text { sindicalizados }\end{array}$ & Total \\
\hline Assalariados* & $\begin{array}{c}880.976 \\
(15 \%)\end{array}$ & $\begin{array}{c}4.906 .105 \\
(85 \%)\end{array}$ & $\begin{array}{c}5.787 .081 \\
(100 \%)\end{array}$ \\
\hline Não assalariados** & $\begin{array}{c}2.548 .756 \\
(30 \%)\end{array}$ & $\begin{array}{c}5.816 .495 \\
(70 \%)\end{array}$ & $\begin{array}{c}8.365 .251 \\
(100 \%)\end{array}$ \\
\hline Total & $\mathbf{3 . 4 2 9 . 7 3 2}$ & $\begin{array}{c}10.722 .600 \\
(76 \%)\end{array}$ & $\begin{array}{c}14.152 .332 \\
(100 \%)\end{array}$ \\
\hline
\end{tabular}

Fonte: Pnad/IBGE. Elaboração própria.

* Assalariados: empregados formais e informais; funcionários públicos estatutários; militares; trabalhadores domésticos formais e informais.

** Não assalariados: conta própria; empregador; trabalhador não remunerado; trabalhador na produção e na construção para consumo próprio.

o caso da Região Sul. Analisando esse tema, Cardoso (2014, p. 125) observa o que corroboraria as principais hipóteses para a compreensão das questões tratadas neste texto:

[...] que, em 1988, 69\% dos filiados no campo eram trabalhadores por conta própria e não renumerados, contra $80 \%$ em 2012. O crescimento se deu, sobretudo, entre os pequenos produtores rurais, provavelmente em razão das regras para acesso ao financiamento da agricultura familiar, e não por uma diferencial propensão desses trabalhadores à sindicalização.

De outra parte, quando cruzamos os dados da Pnad/ IBGE de não assalariados com as regiões do país, percebe-se que esse processo está presente em todas as regiões conforme veremos mais adiante - e hoje, em particular, na Região Nordeste (ver Tabela 3). 


\section{Tabela 3}

Sindicalização rural por região e condição de assalariamento (em \%)

\begin{tabular}{|c|c|c|c|c|c|c|c|c|c|}
\hline Região & Condição & 1992 & 1996 & 1999 & 2002 & 2004 & 2008 & 2012 & 2013 \\
\hline \multirow{2}{*}{ Sudeste } & Assalariados & 13 & 11 & 11 & 13 & 14 & 16 & 14 & 12 \\
\hline & Não assalariados & 11 & 11 & 13 & 22 & 23 & 25 & 27 & 28 \\
\hline \multirow{2}{*}{ Sul } & Assalariados & 25 & 22 & 20 & 19 & 20 & 17 & 18 & 16 \\
\hline & Não assalariados & 29 & 33 & 30 & 36 & 38 & 41 & 38 & 32 \\
\hline \multirow{2}{*}{ Nordeste } & Assalariados & 16 & 15 & 14 & 15 & 17 & 19 & 17 & 19 \\
\hline & Não assalariados & 16 & 18 & 23 & 29 & 32 & 34 & 33 & 35 \\
\hline \multirow{2}{*}{$\begin{array}{l}\text { Centro- } \\
\text {-Oeste }\end{array}$} & Assalariados & 7 & 8 & 7 & 8 & 12 & 11 & 7 & 10 \\
\hline & Não assalariados & 10 & 9 & 9 & 18 & 20 & 21 & 20 & 21 \\
\hline \multirow{2}{*}{ Norte } & Assalariados & 3 & 7 & 4 & 3 & 13 & 14 & 13 & 11 \\
\hline & Não assalariados & 3 & 7 & 8 & 9 & 23 & 24 & 24 & 21 \\
\hline
\end{tabular}

Fonte: Pnad/IBGE. Anos selecionados. Elaboração própria.

A Tabela 3, que trata da sindicalização rural por região segundo a condição de assalariamento, traz dados ainda mais significativos para a compreensão do fenômeno da sindicalização rural não assalariada. Partindo da série histórica que contempla os anos de 1992, 1996, 1999, 2002, 2004, 2008, 2012 e 2013, ou seja, em oito anos selecionados nestes 22 anos, apenas nas regiões Norte e Nordeste o percentual de sindicalizados assalariados e não assalariados eram iguais, no início do período em questão (1992), respectivamente, $3 \%$ e $16 \%$ para essas duas regiões. As outras três regiões já possuíam, nesse ano, mais sindicalizados não assalariados que assalariados. De toda maneira, essa dinâmica só tendeu a aumentar, no período que compreende esses anos, transformando a sindicalização rural em todas as regiões do Brasil em um associativismo de não assalariados.

Nesse sentido, se utilizamos o último ano disponível com os números da Pnad/IBGE 2013, temos, para sindi- 
calizados assalariados e não assalariados por região, respectivamente: Sudeste, $12 \%$ e $28 \%$; Sul, $16 \%$ e $32 \%$; Nordeste, $19 \%$ e $35 \%$; Centro-Oeste, $10 \%$ e $21 \%$ e Norte, $11 \%$ e $21 \%$. Cumpre ressaltar, ainda, no que tange à taxa de sindicalização dos trabalhadores assalariados rurais, que a Região Sul, em 1992, detinha o maior percentual de rurais assalariados sindicalizados, 25\%. Em 2013, essa taxa caiu para $16 \%$. Inversamente, o Nordeste, que inicia o período em questão com 16\% (1992), chega em 2013 com 19\%. Em outras palavras, além de possuir a maior taxa de sindicalização rural assalariada, é também a região do país onde se concentra o maior percentual de não assalariados rurais: $35 \%$.

Quais as explicações plausíveis para o entendimento desse processo? De forma resumida, poderíamos dizer que, em primeiro lugar, como já mencionado aqui, destacam-se as políticas voltadas para os trabalhadores rurais, no tocan-

118 te à previdência social, salário, aposentadorias etc., que vêm sendo levadas adiante desde os anos de 1960 com o Estatuto do Trabalhador Rural e o Estatuto da Terra, por exemplo, passando pelo Funrural a partir de 1971, com suas respectivas mudanças em 1975. Em segundo lugar, em 1988, a promulgação da Constituição trouxe novos direitos aos trabalhadores rurais. Já, em meados da década de 1990, a instituição do Pronaf criou as condições de incorporar de forma mais sistemática, ainda que no seu início em bases bastante tímidas, os agricultores familiares, além de outros setores. Essa dinâmica se acentuou a partir de 2003, com os governos Lula e Dilma, no que diz respeito às políticas públicas de inclusão social e ao aumento significativo do volume de recursos voltados à agricultura familiar. Certamente, o conjunto dessas questões que foram amadurecendo nas últimas décadas trouxe importantes mudanças na ação sindical rural e, em alguma medida, transformou a dialética das relações do trabalhador assa- 
lariado e não assalariado no campo e criou as condições para as transformações captadas, nesse âmbito, por este estudo e outras pesquisas que tratam dessa temática, pelo menos, nas últimas duas décadas no país. Some-se a isso a ação organizada dos trabalhadores rurais desde o final dos anos de 1970 e a atuação da chamada Igreja progressista, ligada à Teologia da Libertação, junto às comunidades rurais, assim como as políticas públicas no período, fatores que, com pesos distintos, foram decisivos para explicar o quadro atual. Desse modo, todo esse processo criou um caldo de cultura que nos ajuda a entender essa questão, ilustrada na Tabela $3^{12}$.

De outra parte, a Tabela 4 ilustra a sindicalização rural por gênero nos anos de 1992 e 2013. Há, entre os sindicalizados rurais, um crescimento significativo da participação feminina no total dos sindicalizados do setor: em 1992, apenas $20 \%$ dos sindicalizados do campo eram mulheres, contra $80 \%$ dos homens. Já, em 2013, há uma diminuição da sindicalização masculina, que cai para $59 \%$, e o forte crescimento, nesses vinte dois anos, do associativismo feminino, que sobe de $20 \%$, no início da década de 1990 , para $41 \%$, em 2013. Vale dizer que a taxa de sindicalização feminina mais que dobrou no período.

Discutindo a questão da previdência social para os trabalhadores rurais, Brumer (2002, pp. 52-53) chama a atenção para o fato de que

[...] se a inclusão dos trabalhadores rurais foi tardia em relação a outras categorias profissionais, a inclusão das

\footnotetext{
${ }^{12}$ Em estudo recente, o Dieese, analisando o trabalhador assalariado rural no Brasil, afirma que o número aproximado dos trabalhadores rurais ligados à agricultura familiar no país, no conjunto da população ocupada, seria de, aproximadamente, 9,6 milhões de pessoas em 2013. Neste caso, população ocupada com 10 anos ou mais de idade. O referido estudo trata, especificamente, dos trabalhadores assalariados rurais (cf. Dieese, 2014, p. 9).
} 
mulheres rurais trabalhadoras ocorreu ainda mais tarde, principalmente porque, para poder receber os benefícios da previdência social deviam, antes de mais nada, ser reconhecidas como trabalhadoras rurais [...] Assim, no início consideradas como "dependentes" seja dos pais ou dos maridos, passam paulatinamente a serem vistas como "autônomas", portadoras de direitos individuais, o que lhes permite serem incorporadas como beneficiárias da previdência social.

Beatriz Heredia e Rosângela Cintrão (2006, p. 6) também atentaram para a participação das mulheres nos movimentos sociais rurais. De acordo com as autoras, esses movimentos no campo têm "favorecido o acesso das mulheres a direitos e a políticas públicas”.

Em resumo, essas são, certamente, questões pontuais para a compreensão do processo de associativismo das tra-

120 balhadoras rurais nas últimas décadas.

Tabela 4

Sindicalização rural por gênero (1992 e 2013)

\begin{tabular}{|c|c|c|}
\cline { 2 - 3 } \multicolumn{1}{c|}{} & 1992 & 2013 \\
\hline Masculino & $\begin{array}{c}1.875 .427 \\
(80 \%)\end{array}$ & $\begin{array}{c}2.026 .101 \\
(59 \%)\end{array}$ \\
\hline Feminino & 460.323 & 1.403 .631 \\
& $(20 \%)$ & $(41 \%)$ \\
\hline Total & 2.335 .750 & 3.429 .732 \\
& $(100 \%)$ & $(100 \%)$ \\
\hline
\end{tabular}

Fonte: Pnad/IBGE. Elaboração própria.

O Gráfico 4 apresenta dados recentes do Ministério do Trabalho e Emprego (MTE), relacionados ao peso dos trabalhadores rurais e urbanos associados às principais centrais sindicais no Brasil, reconhecidas pelo MTE, quando da afe- 
rição sindical para efeito de repasse dos recursos destinados às centrais sindicais de acordo com a Lei $\mathrm{n}^{\circ} 11.648 / 2008$.

Observa-se, no Gráfico 4, que o maior peso dos trabalhadores rurais está em entidades sem filiação a qualquer central sindical (54\%), indicando que há um campo expressivo para a disputa entre as centrais sindicais na ampliação de sua representação no meio rural. A CTB é a central que tem maior peso de associação de trabalhadores rurais em sua base social (25\%), seguida pela CUT (18\%). Há que ponderar que tais percentuais podem estar superestimados ou subestimados, uma vez que o critério do MTE baseia-se em aferição a partir do registro atualizado das entidades, o que frequentemente destoa dos dados das centrais, para quem vale a filiação política, independentemente da situação regularizada ou não delas junto ao MTE.

\section{Gráfico 4}

Trabalhadores urbanos e rurais filiados às Centrais (Brasil, 2013) (em \%)

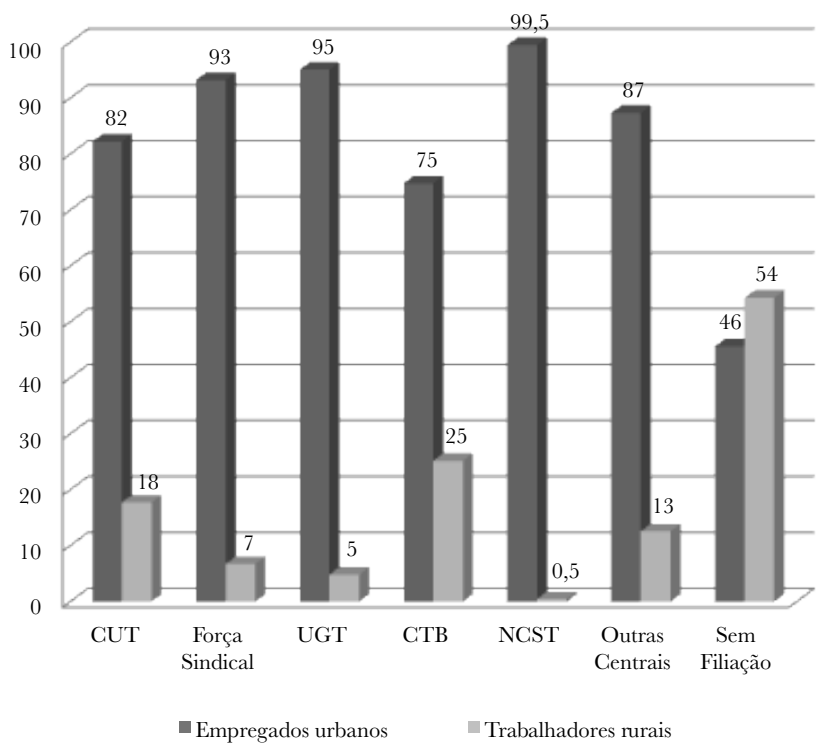

Fonte: MTE (2013). Elaboração própria. 


\section{A participação rural na CUT: base e direção}

Dados da Central Única dos Trabalhadores sobre a sua base de sindicatos e trabalhadores associados guardam uma relação muito próxima com as questões tratadas nas seções anteriores deste artigo: representavam, em 2013, quase 4 mil sindicatos filiados e o número de trabalhadores na base desses sindicatos chegava a, aproximadamente, 24 milhões, e destes, mais de 7,8 milhões seriam sindicalizados (CUT, 2013). De outra parte, quase $40 \%$ dessas instituições eram entidades rurais (1.458), e um pouco mais de um terço era proveniente do setor público ${ }^{13} \mathrm{e} /$ ou relacionado a ele.

Os dados acerca do número de sindicatos filiados e de trabalhadores associados aos sindicatos diferem significativamente entre o informado pela própria CUT e o disponibilizado pela aferição do MTE. A razão para tal discrepância se deve, principalmente, ao fato de o Ministério só contabilizar as entidades devidamente registradas e atualizadas em seu sis-

122 tema, o que deve ocorrer a cada eleição sindical, como uma reafirmação de que a chapa eleita manterá seu vínculo com a respectiva central. Desse modo, um sindicato cutista que, por qualquer motivo, não esteja com a documentação em dia no MTE não será computado para os critérios de representatividade da Lei $\mathrm{n}^{\circ} 11.648$. No entanto, a mesma entidade constará no cadastro da CUT e terá todos os seus direitos de associada para indicação de delegados(as) aos congressos e plenárias se estiver cumprindo com suas atribuições estatutárias. A atualização cadastral das entidades filiadas junto ao MTE é uma das principais preocupações da CUT na atualidade, bem como das demais centrais, tendo em vista os recursos que são repassados a essas instituições.

O Gráfico 5 e a Tabela 5 ilustram, mais detalhadamente, as tendências anteriormente referidas. A distribuição, por região, dos sindicatos cutistas mostra que a maior concentração está

${ }^{13}$ Neste artigo, nos ateremos apenas à questão dos trabalhadores rurais. 


\section{Gráfico 5}

Taxa de sindicalização por região (Brasil, 2013)

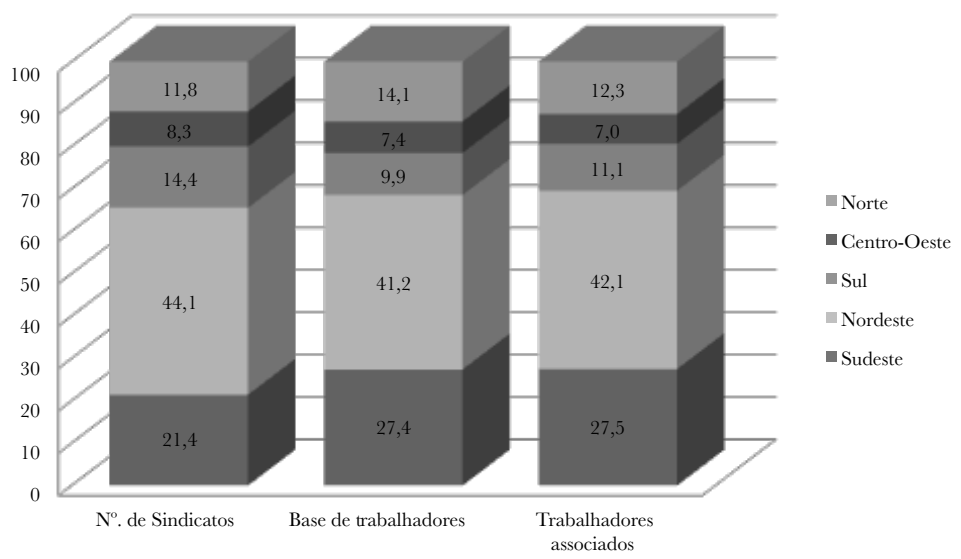

Fonte: CUT (2013). Elaboração própria.

no Nordeste, com 44\%; seguida do Sudeste, com $21 \%$, e do Sul, com $14 \%$. Já no que tange à base de trabalhadores ${ }^{14}$, os principais contingentes se encontram, por ordem decrescente: Nordeste (41\%), Sudeste (27\%) e Norte (14\%). Entre os trabalhadores associados, temos também em ordem decrescente: Nordeste (42\%), Sudeste (27\%), Norte (12\%) e

14 No caso de assalariados, a base de trabalhadores significa a soma de todos os trabalhadores com vínculo empregatício em empresas da base de representação do sindicato, cobertos pelo instrumento da Convenção Coletiva de Trabalho, independentemente de ser ou não associado(a) ao sindicato. Excetua-se desse total os empregados que pertencem às chamadas categorias diferenciadas dentro da empresa (p. ex.: engenheiros agrônomos, técnicos agrícolas, secretárias etc.), bem como, evidentemente, empregados de empresas terceirizadas e/ou prestadoras de serviço que, mesmo trabalhando no mesmo local, pertençam a outra categoria econômica e tenham um sindicato próprio (p. ex.: vigilantes, pessoal de limpeza etc.). Trabalhadores temporários compõem parte da categoria, mas dificilmente tornam-se associados, devido à precariedade de seu vínculo empregatício. No caso dos não assalariados, dada a informalidade que caracteriza a situação laboral, considera-se a base de trabalhadores todos os moradores de uma comunidade rural, por exemplo. Observa-se que a base de trabalhadores não assalariados rurais é imprecisa. Trabalhadores associados, sejam assalariados ou não assalariados, são todos aqueles que estão filiados, voluntariamente, ao quadro de sócios do sindicato. 
Sul (11\%). Em outras palavras, o que os dados mostram é que a Região Nordeste é aquela em que a CUT tem o maior número de sindicatos e, por extensão, a maior base de trabalhadores, bem como o maior contingente de sindicalizados. De outra parte, quando se redimensiona a base da central entre aqueles trabalhadores com atividades urbanas e aqueles com atividades rurais, observa-se que quase a metade é oriunda do campo. Ou seja, quando se reordena essa mesma categorização, número de sindicatos, base de trabalhadores e trabalhadores associados pela relação rural/urbano, observa-se que a quantidade de sindicatos rurais representa, no universo da CUT, aproximadamente $40 \%$; a base de trabalhadores rurais é $44 \%$ e os trabalhadores associados aos sindicatos rurais e/ ou associações rurais ligados à CUT se aproximam da metade, perfazendo $46 \%$ do total dos sindicalizados dessa Central. Em termos absolutos, em 2013, os trabalhadores urbanos representavam cerca de 4 milhões e 200 mil associados à Central 124 contra, aproximadamente, 3 milhões e 600 mil sindicalizados ligados às atividades no campo. Esse processo, no entanto, não é novo no sindicalismo brasileiro. Segundo Maria Hermínia Tavares de Almeida (1983, p. 196; grifos nossos),

[...] em 1960, os sindicatos ainda não haviam chegado ao campo e, no meio urbano, organizavam pouco menos de um milhão e meio de pessoas. Dezoito anos depois [1978], formavam uma massa de quase 10 milhões, dos quais mais $d a$ metade na zona rural.

Ou seja, esse padrão de sindicalização rural, com todos os ingredientes que representa para a ação sindical no Brasil, tem se mostrado consistente desde a segunda metade da década de 1970. Apesar de dados estatísticos ainda precários, todos os indicadores apontam na mesma direção: crescimento em números absolutos e relativos do associativismo rural, assim como da importância da atuação desse setor para o 
conjunto do sindicalismo brasileiro ${ }^{15}$ e uma queda persistente da sindicalização nas áreas urbanas, particularmente entre aqueles setores que foram fundamentais para a eclosão do movimento grevista no Brasil em 1978: o setor industrial e, em seu interior, os metalúrgicos.

Tabela 5

CUT: sindicalização urbana e rural (2013)

\begin{tabular}{|c|c|c|c|}
\cline { 2 - 4 } \multicolumn{1}{c|}{} & $\mathbf{N}^{\mathbf{0}}$ de sindicatos & $\begin{array}{c}\text { Base de } \\
\text { trabalhadores }\end{array}$ & $\begin{array}{c}\text { Trabalhadores } \\
\text { associados }\end{array}$ \\
\hline Atividades urbanas & 2.339 & $\begin{array}{c}13.325 .061 \\
(56 \%)\end{array}$ & $\begin{array}{c}4.207 .594 \\
(54 \%)\end{array}$ \\
\hline \multirow{2}{*}{ Atividades rurais } & 1.458 & 10.454 .889 & 3.639 .210 \\
& $(38 \%)$ & $(44 \%)$ & $(46 \%)$ \\
\hline Total & 3.797 & $\mathbf{2 3 . 7 7 9 . 9 5 0}$ & $\mathbf{7 . 8 4 6 . 8 0 4}$ \\
& $(100 \%)$ & $(100 \%)$ & $(100 \%)$ \\
\hline
\end{tabular}

Fonte: CUT (2013). Elaboração própria.

De outra parte, Maria Hermínia chama a atenção para a utilização dos dados de sindicalização, à época, ainda bem mais precários que nos dias de hoje. No entanto, como dissemos antes, mesmo atualmente as estatísticas sobre associativismo sindical não são tão precisas e, como são utilizadas, por vezes, metodologias diferentes, é importante que olhemos muito mais para as tendências indicadas que para o dado em si. Nesse sentido,

[...] estes devem ser tomados pelo que são: uma medida imprecisa da adesão formal aos sindicatos, que nada informa sobre o grau de participação efetiva dos associados na vida de suas entidades representativas [...] e que, tratados com a devida cautela, podem ser considerados um indicador

${ }^{15}$ Sobre a expansão do sindicalismo rural no Brasil pós-64, ver também Erickson (1979, p. 211). 
eloquente do fato de que, à diferença do passado, hoje, [início dos anos 1980] o movimento sindical brasileiro tem, virtualmente, uma base de massas. Em graus e formas variáveis, cerca de 10 milhões de trabalhadores fazem parte do mundo dos sindicatos e constituem um potencial de mobilização de porte significativo (Almeida, 1983, p. 196).

Corroborando essas questões relacionadas ao crescimento do associativismo no campo, Maria Helena Moreira Alves (1984, pp. 243-44) afirma que

[...] os sindicatos rurais foram os que mais cresceram sob o Estado de Segurança Nacional tendo sido, em grande parte, organizados pela oposição. Esta organização foi levada a efeito em estreita colaboração com as organizações da Igreja Católica para a defesa de camponeses sem terra e dos direitos dos posseiros, e com as comunidades de base rurais. Os organizadores dos sindicatos rurais têm obtido mais êxito que seus colegas urbanos na implantação de um sistema democrático de funcionamento no quadro da estrutura sindical oficial.

Ainda, de acordo com a autora, "diferentemente das federações urbanas, muitas das federações rurais têm lutado vigorosamente na defesa dos direitos dos trabalhadores do campo e do direito à terra”. No que concerne às estatísticas na década de 1970, utilizando como fonte o IBGE, a Contag e o setor de informática da Câmara dos Deputados, Alves (1984) enumera para os anos de 1974, 1976, 1977, 1978 e 1979, respectivamente, cerca de 3 milhões, 3,5 milhões, 4 milhões, 4,5 milhões e um pouco mais de 5 milhões de trabalhadores rurais associados às suas entidades sindicais. Esses dados, em geral, são indicativos de que a tendência ao crescimento da sindicalização rural no Brasil vem desde os anos de 1970, o que significa dizer que tem perdurado 
nas últimas quatro décadas, processo que estaria indo na contramão do associativismo sindical urbano, mesmo guardadas as especificidades desse setor.

Nesse sentido, Regina Reyes Novaes (1991, p. 176) destaca o papel desempenhado pela "Igreja Católica, diretamente envolvida na fundação de sindicatos no campo". A autora acentua, ainda, o fato de que

[...] na década de 70 foram fundados $46 \%$ dos 2.732 sindicatos de trabalhadores rurais recenseados em 1989, e é possível relacioná-los com a busca de aposentadoria, pensões, auxílios-funeral, serviços de saúde. Por outro lado, dirigentes sindicais ligados à Contag interpretam essa aceitação do fardo previdenciário como tática do MSTR [Movimento Sindical dos Trabalhadores Rurais], para estimular a sindicalização e, principalmente, para evitar que os recursos [e] o controle da assistência ficassem nas mãos dos políticos locais (Novaes, 1991, pp. 178-79).

Em resumo, para além das especificidades do movimento sindical rural, das suas características regionais, das formas diferenciadas do trabalho no campo, o mesmo indivíduo é e/ou pode ser, a um só tempo, pequeno produtor familiar e trabalhador assalariado, para ficarmos apenas em um exemplo, os fatores acima mencionados funcionaram como a base para a rearticulação das lutas no campo e, em parte, explicariam o processo continuado de crescimento do associativismo rural no Brasil desde a década de 1970. Assim, de forma geral, o peso dos rurais entre os trabalhadores sindicalizados no Brasil e, especificamente, no interior da CUT, não é por acaso $^{16}$. Está ancorado fortemente, de um lado, na realidade

\footnotetext{
${ }^{16}$ Segundo dados do Ministério do Trabalho e Emprego, mostrados antes no Gráfico 4 deste artigo, a CTB é a central que possuiria o maior peso relativo de sindicalização rural entre as centrais sindicais: $25 \%$ de seus associados vêm do campo contra $75 \%$ das áreas urbanas.
} 
das demandas daqueles que labutam a terra em nosso país e, de outro, nas políticas, sejam elas assistenciais, sejam de incentivo à agricultura familiar e/ou inclusão social, que foram sendo gestadas em todos esses anos.

Nesse aspecto, poderíamos dizer que a CUT, por sua trajetória entre as classes trabalhadoras no Brasil nestas últimas três décadas e por razões apontadas neste estudo, se transformou em estuário de parcelas ponderáveis do sindicalismo rural no Brasil, tanto de trabalhadores assalariados quanto daqueles não assalariados, certamente, neste caso, uma proporção significativa de trabalhadores oriundos da agricultura familiar, conforme veremos a seguir.

Ocorre, no entanto, que esse expressivo número de sindicalizados rurais na CUT, seja em termos absolutos quanto relativos, não se reflete nos organismos de representação da Central. Pelo contrário, a despeito da participação significativa dos trabalhadores rurais nos primeiros quatro congressos 128 (1983, 1984, 1986 e 1988), como já mencionado, de mais de $30 \%$ do conjunto dos delegados nos referidos congressos e, naquele congresso de fundação, em 1983, os representantes rurais serem quase a metade dos delegados presentes $(44,7 \%$ ) - conforme ilustra o Gráfico 6 -, no âmbito das instâncias organizativas ocorreu, em larga medida, um acentuado declínio da presença desse segmento do ponto de vista de sua participação efetiva, seja no contingente de participantes como delegados, seja no âmbito das instâncias decisórias, cujo exemplo mais claro é a composição, por setores de atividade na direção executiva dessa instituição, conforme mostraremos adiante. Uma das razões se deveria à questão, já tratada aqui, da mudança dos estatutos da CUT no $3^{\circ}$ Concut (em 1988), com os novos critérios de representatividade para participação nos congressos. Daquele momento em diante, a quantidade de delegados nos congressos da CUT teria de ser uma proporção do número de associados, e não do número de trabalhadores de base (sócios ou não do sindicato). Nesse 
sentido, o percentual sobre uma base mais restrita reduziu o número de delegados e, diante do cenário de disputas congressuais, tornou-se praxe que somente os membros das diretorias dos sindicatos fossem eleitos para participar desses eventos, o que teria levado a uma drástica queda na participação rural nos congressos da CUT (sobretudo da base), conforme se vê no Gráfico 6.

\section{Gráfico 6}

Taxa de participação das delegações rurais nos Concuts (anos selecionados)

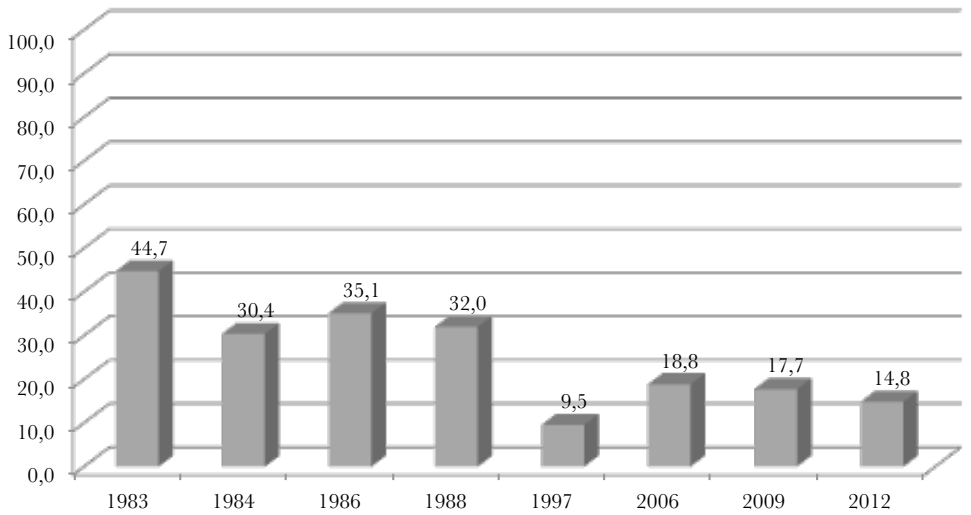

Fonte: Resoluções Concut. Elaboração própria.

No que tange ao perfil da executiva nacional da CUT, os dados apresentados na Tabela 6 e no Gráfico 7 foram colhidos a partir de levantamento de todas as gestões eleitas, desde o congresso de fundação, em 1983, até o congresso mais recente, realizado em 2012, cujo mandato se encerrará em 2015. Vale dizer, foram analisados os doze congressos que a Central organizou em seus 31 anos de existência. Cumpre observar que, ao final de cada congresso, são editadas suas resoluções, que, além de conter uma análise política, econômica e social da conjuntura brasileira, traz também um balanço do mandato que se encerra e um plano de lutas que norteia as ações da direção que se inicia a partir do congresso. Os cadernos de 
resolução abordam ainda questões pertinentes às secretarias existentes na CUT nacional, tais como o tema das mulheres, da juventude, do combate ao racismo, da saúde do trabalhador, da formação sindical, meio ambiente etc. De outra parte, ao final do documento, é listada a diretoria executiva eleita e, ao lado do nome do sindicalista, aparece também a respectiva instituição sindical à qual está filiado. Essas informações serviram para a elaboração da Tabela 6 e do Gráfico 7, com base em onze variáveis: mandato, cargo dentro da executiva ${ }^{17}$, município, estado, região do país, rural/urbano, macrossetor ${ }^{18}$, ramo, categoria profissional $^{19}$, gênero e o tipo de entidade ${ }^{20}$. Para os objetivos deste artigo, no entanto, foram utilizadas apenas as informações relacionadas ao setor de atividade e à distinção entre rural e urbano.

Dezoito estados (perfazendo um total de cinquenta municípios) tiveram representação na executiva da CUT: sete da Região Nordeste, quatro da Região Sudeste, três da Região 130 Sul e dois das região Norte e dois da Centro-Oeste. São Paulo é o estado com maior representação, com 34,6\% de todos os membros da executiva ao longo da história da CUT, seguido por Rio Grande do Sul (8,7\%), Minas Gerais (8,4\%), Rio de Janeiro $(7,5 \%)$ e Bahia $(6,2 \%)$.

\footnotetext{
${ }^{17}$ Por "cargo na executiva", definimos três variáveis: "executiva" aos membros com cargo na presidência, vice-presidência, secretaria geral e tesouraria; "secretariado" aos membros que têm a titularidade em alguma secretaria específica, como formação, comunicação, política sindical etc.; e "direção executiva" àqueles que participam da executiva sem a titularidade em qualquer pasta.

${ }_{18}$ Por "macrossetor", adotamos a mesma definição utilizada pela organização da CUT: indústria, comércio e serviços, setor público e rural.

19 Adotamos a mesma definição de "ramos" da CUT e consideramos "categoria profissional" como a área mais específica do dirigente dentro do ramo. Por exemplo, no ramo químico, encontramos três categorias profissionais, como petroleiro, químico e plástico. No ramo de transporte, há categorias profissionais como metroviário e portuário, e assim por diante. Foram identificados ao todo 15 ramos e 33 categorias profissionais.

${ }^{20}$ Por "tipo de entidade", consideramos as variáveis "sindicato", "associação", "oposição sindical" e "federação nacional", "federação interestadual" e "federação estadual", conforme a entidade pela qual o membro havia sido indicado delegado ao congresso que o elegeu para a executiva.
} 
O que esses dados nos dizem? Na Tabela 6, por exemplo, se compararmos a representação na executiva por setor de atividade no congresso de fundação da CUT, gestão 1983-1984, e no $11^{\circ}$ Concut, gestão 2012-2015, observamos que dois setores diminuíram sua participação: houve queda de militantes sindicais oriundos do setor industrial e decréscimo, ainda maior, da representação rural na direção da central. De outra parte, dois setores cresceram fortemente: comércio/serviços tinha cerca de $20 \%$ em 1983 e alcança o patamar de quase $35 \%$ em 2012; já o crescimento do setor público é muito mais significativo, de pouco mais de $7 \%$ em 1983, chega a 25\% em 2012. De toda forma, o aspecto mais importante que tanto esse quadro quanto o seguinte nos mostram é o processo de sub-representação do sindicalismo rural nas instâncias organizativas dessa Central diante da taxa de sindicalizados desse setor pertencentes a ela.

Tabela 6

Direção executiva da CUT por setor de atividade (em \%)

\begin{tabular}{|c|c|c|c|c|c|}
\hline Concut/Gestão & Rural & Indústria & $\begin{array}{c}\text { Comércio/ } \\
\text { Serviços }\end{array}$ & $\begin{array}{c}\text { Setor } \\
\text { público }\end{array}$ & Total \\
\hline Fundação (1983-1984) & 28,6 & 42,9 & 21,4 & 7,1 & 100,0 \\
\hline $1^{\circ}(1984-1986)$ & 22,2 & 38,9 & 22,2 & 16,7 & 100,0 \\
\hline $2^{\circ}(1986-1988)$ & 15,0 & 35,0 & 25,0 & 25,0 & 100,0 \\
\hline $3^{\circ}(1988-1991)$ & 10,0 & 35,0 & 35,0 & 20,0 & 100,0 \\
\hline $4^{\circ}(1991-1994)$ & 6,5 & 35,5 & 29,0 & 29,0 & 100,0 \\
\hline $5^{\circ}(1994-1997)$ & 6,3 & 28,1 & 34,3 & 31,3 & 100,0 \\
\hline $6^{\circ}(1997-2000)$ & 9,4 & 34,3 & 31,3 & 25,0 & 100,0 \\
\hline $7^{\circ}(2000-2003)$ & 12,5 & 28,1 & 31,3 & 28,1 & 100,0 \\
\hline $8^{\circ}(2003-2006)$ & 9,7 & 22,6 & 41,9 & 25,8 & 100,0 \\
\hline $9^{\circ}(2006-2009)$ & 12,5 & 18,8 & 31,2 & 37,5 & 100,0 \\
\hline $10^{\circ}(2009-2012)$ & 14,8 & 25,9 & 33,4 & 25,9 & 100,0 \\
\hline $11^{\circ}(2012-2015)$ & 12,5 & 28,1 & 34,4 & 25,0 & 100,0 \\
\hline Total & 12,1 & 29,9 & 31,8 & 26,2 & 100,0 \\
\hline
\end{tabular}

Fonte: Resoluções Concut. Elaboração própria. 
Já o Gráfico 7 trata, mais especificamente, da dicotomia rural/urbana nos organismos de direção da Central, e ilustra, de forma ainda mais clara, a sub-representação dos rurais no âmbito da instituição. No congresso de fundação da CUT, em 1983, a participação dos trabalhadores do campo na direção executiva alcançou quase $30 \%$. Nos congressos seguintes, ocorreu acentuada queda dessa participação até chegar no $4^{\circ}$ e no $5^{\circ}$ Concut com apenas $6 \%$ de participação nessa arena decisória. A partir do congresso seguinte, em 1997, ocorre, com pequenas variações, aumento percentual de rurais na direção da central, mas nada muito significativo, levando-se em conta o peso numérico dos trabalhadores rurais a ela associados: no penúltimo congresso alcançou $15 \%$ e, no último, em 2012, caiu para 12\%. O que explicaria essa discrepância?

Ao analisar a composição da executiva nacional que resultou do $3^{\circ}$ Concut, Leôncio Martins Rodrigues (1990, p. 57) 132 apontava o fato de que, em um conjunto de quinze membros, havia "apenas um dirigente dos trabalhadores rurais

\section{Gráfico 7}

Direção executiva da CUT rural e urbana

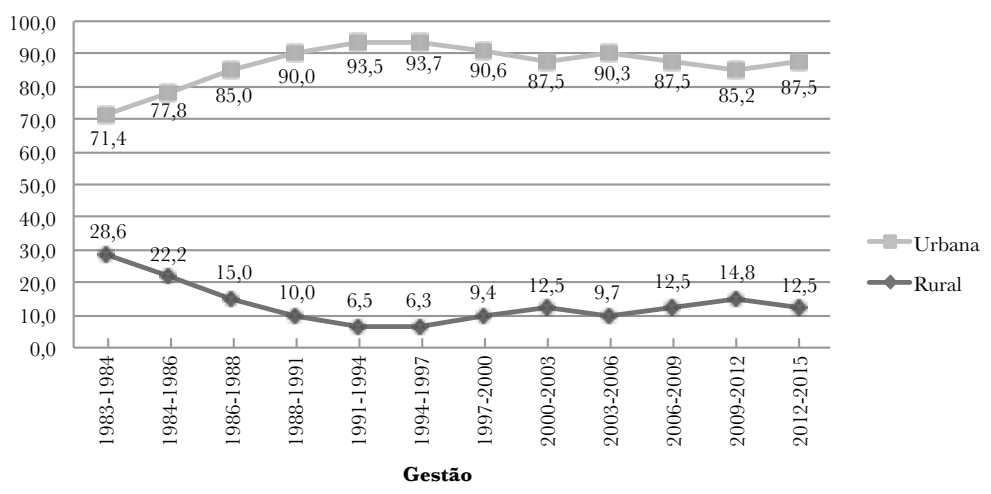

Fonte: Resoluções Concut. Elaboração própria. 
(entre os cinco suplentes, há mais um)". Discorrendo, ainda, sobre a composição dos delegados desse congresso, o autor observa:

[...] chama a atenção, de um lado, o alto nível de escolaridade de grande parte dos delegados, muito acima da maioria da classe trabalhadora brasileira, do eleitorado e da população do país. Mas chama a atenção, por outro lado, a proporção elevada de trabalhadores com baixíssimo nível de escolaridade, notadamente entre os trabalhadores rurais. Ambos os fenômenos têm diretamente uma mesma raiz: a composição social e profissional muito heterogênea da CUT, reunindo trabalhadores do setor urbano e do setor rural não só numa mesma entidade como também num mesmo congresso (Rodrigues, 1990, p. 81).

Por fim, esse autor afirma que,

[...] na CUT, a presença de trabalhadores rurais (na maior parte das vezes, pequenos proprietários), empregados de estatais e trabalhadores do setor privado implica um esforço, frequentemente artificial, de harmonização de reivindicações que têm coeficientes de motivação e força de mobilização diferentes para cada um desses três grandes grupos (Rodrigues, 1990, p. 81).

Vale dizer, são várias as "CUTs", várias as práticas sindicais em seu interior e, por vezes, diferentes os discursos. Esse aparente gigantismo da Central leva, em alguns momentos, a uma dialética de força e fraqueza em suas ações e à dificuldade de contemplar interesses, demandas e questões múltiplas que são, por vezes, aparentemente, contraditórias. E, certamente, esses aspectos têm levado, nestes mais de trinta anos da história da CUT, há um processo de 
sub-representação dos trabalhadores rurais em seus organismos de direção, como exemplifica o Gráfico 7.

A CUT completou trinta anos em 2013. Fundada em agosto de 1983, como expressão de um setor sindical que realizou tanto as grandes greves do período 1978-1980 quanto as paralisações de fábricas, cujas demandas por aumento de salários, contra o despotismo no interior dos locais de trabalho, melhorias nas condições de trabalho no campo e na cidade sacudiram o país no final dos anos de 1970. Esse movimento foi responsável, em alguma medida, por vocalizar as demandas de amplos setores da sociedade brasileira na luta contra a ditadura militar, pela redemocratização e por direitos em nosso país. A CUT foi, a um só tempo, naquele momento, catalizadora e impulsionadora desse 134 processo.

Passados mais de três décadas do seu surgimento, a CUT é, hoje, um ator sindical e político extremamente relevante na cena pública nacional; é a maior central sindical brasileira e da América Latina e uma das maiores do mundo: possui 3.797 sindicatos filiados e o número de trabalhadores na base dessas entidades chega a quase 24 milhões, e destes, 7,8 milhões seriam sindicalizados (CUT, 2013). De outra parte, quase $40 \%$ dessas instituições são sindicatos rurais e cerca da metade dos trabalhadores sindicalizados na Central são oriundos do campo.

Nesse sentido, um dos principais paradoxos do sindicalismo brasileiro e, em especial, da Central Única dos Trabalhadores, é a forma como essa instituição lida, no plano político-sindical-organizativo, com os seus associados rurais.

Como o texto procura demonstrar, no que tange à organização dos trabalhadores rurais, mesmo estes tendo uma expressiva força que se traduz em número de filiados, 
número de sindicatos e base de trabalhadores e em capacidade de mobilização de suas entidades na defesa de suas demandas, no interior do sindicalismo CUT, esse setor tem um peso diminuto nos órgãos decisórios da Central. Uma explicação reside no fato de que a representação rural é muito dispersa e, dada a conformação geográfica do Brasil, as distâncias dificultam o trabalho sindical se comparado com as áreas urbanas; a mescla de sindicatos de assalariados e também de não assalariados, entre outros aspectos, trazem óbice à atuação do sindicalismo rural etc.

De toda forma, a despeito dos problemas enfrentados pelos trabalhadores rurais e suas organizações, chama a atenção, conforme mostram os dados aqui discutidos, o crescente aumento da sindicalização rural nas últimas décadas: tanto entre os assalariados quanto entre os trabalhadores não assalariados no campo. E, entre estes últimos, o aumento da taxa de sindicalização em maior proporção que entre os primeiros. Esse processo está ancorado nas políticas públicas voltadas a esse setor desde os anos de 1960, como as medidas tomadas pelo governo João Goulart, passando por várias iniciativas nos governos militares, pela Constituição de 1988, pela criação do Pronaf nos anos de 1990, no período FHC, no que tange à agricultura familiar, por exemplo, e à ampliação - sem precedentes - em grande parte desses programas e a criação de novos, com um volume de recursos inéditos a partir de 2003, nos governos Lula e Dilma. Todos esses aspectos certamente levaram ao incremento do associativismo rural nas últimas quatro décadas. Em outras palavras, a luta dos trabalhadores rurais por equiparação de direitos com os empregados urbanos, por demandas específicas de luta pela terra, por reivindicações de políticas agrícolas adequadas aos agricultores familiares foram questões que encontraram solo "fértil" para se desenvolverem, dadas as profundas desigualdades encontradas no campo brasileiro em todos esses anos. 
Faz-se necessário, no entanto, sublinhar o papel chave desempenhado por um ator que foi a "base" da organização desse movimento pelo país afora no pós-1964 e nos anos de 1970: a Igreja Católica. De certa forma, essa instituição funcionou como uma espécie de catalizadora, por sua capilaridade nas várias regiões do Brasil e, em especial, na zona rural, desse processo de organização mais amplo que desembocou, inclusive, na fundação da CUT em 1983. O fato de, no congresso de fundação, a delegação rural representar quase a metade desse encontro diz muito do papel desempenhado por essa instituição e pelas Comunidades Eclesiais de Base (CEBs) nesse processo, naquele momento (Rodrigues, 2011, pp. 65-69).

A imagem construída pela CUT nos anos de 1980 esteve fortemente ancorada, simbolicamente, nos metalúrgicos, sobretudo devido às lutas conduzidas na região do $\mathrm{ABC}$ paulista. De lá saíram importantes lideranças que têm se 136 destacado no cenário político nacional. Seu maior exemplo: Luiz Inácio Lula da Silva.

A partir dos anos de 1990, quando o funcionalismo público em geral passou ao centro dos ataques e torna-se parte da resistência à política neoliberal que então se implantava no país, o sindicalismo do setor público assume a primazia na imagem simbólica da CUT na sociedade. Por vezes, outras categorias plasmaram o imaginário social dessa instituição sindical, como os petroleiros na greve iniciada em 3 de maio de 1995 e que durou 32 dias.

Os trabalhadores rurais, no entanto - principalmente aqueles da agricultura familiar -, nunca expressaram a face pública da CUT no país. Possivelmente, tenham maior visibilidade em uma ou outra região em que predomine essa atividade econômica, mas não no país como um todo.

O objetivo deste artigo foi analisar esse segmento que sempre teve uma presença significativa no sindicalismo 
CUT e demonstrar que é no âmbito do trabalho rural que a Central tem tido índices mais relevantes de crescimento da sindicalização nos últimos anos, sobretudo nas regiões Nordeste e Sul, em que a atividade da agricultura familiar melhor representa a alternativa de um projeto de desenvolvimento e o enfrentamento histórico à exclusão social.

Quem sabe, no contexto dos últimos dez anos, a imagem que melhor simboliza a CUT não seja a de um trabalhador rural e sua família, plantando e criando animais, com um pequeno trator ou um arado? Uma imagem impensável doze ou trinta anos atrás...

Por fim, o texto analisou as relações entre os trabalhadores rurais, o sindicalismo no campo e a Central Única dos Trabalhadores. Nesse sentido, é importante sublinhar que, proporcionalmente, como mostram os dados apresentados, o associativismo rural é maior que a sindicalização dos trabalhadores urbanos. De outra parte, quando se analisa as taxas de sindicalização no campo, chama a atenção o significativo aumento e preponderância de trabalhadores não assalariados, oriundos principalmente da agricultura familiar, no incremento das taxas de sindicalização. E isso ocorre em todas as regiões do país. Com relação à questão de gênero, outra novidade: o acentuado crescimento da sindicalização feminina na zona rural. Além disso, as regiões com maior sindicalização são, hoje, por ordem decrescente, o Nordeste e o Sul, com a ressalva de que a Região Nordeste é a única que tem mostrado um crescimento consistente e ascendente, tanto na sindicalização dos rurais assalariados quanto dos não assalariados. Em alguma medida, os dados da CUT com relação ao associativismo rural em suas fileiras, com quase metade de seus sindicalizados sendo oriundos do campo, apenas comprovam as tendências, no fundo, expressas nas estatísticas da Pnad/IBGE e do Ministério do Trabalho. Isso não significa dizer que a CUT se transformou em uma central 
sindical rural, mas talvez possamos afirmar, com base nos dados disponíveis, que ela tem conseguido mais eficácia em trazer para os seus quadros de associados, pelas razões expostas neste artigo, os trabalhadores rurais, a despeito da sub-representação desse setor nos organismos de representação da Central.

Em trabalho recente, Lima (2014, p. 31), discorrendo sobre a temática do trabalho, observa que este

[...] não permite sua redução a dicotomias tais como assalariado-não assalariado; com direitos-sem direitos; precarização-emancipação, entre outros que ajudam a perceber a árvore, mas não permitem visualizar a floresta. Dessa forma, a análise do trabalho se insere na compreensão da sociedade em seu desenvolvimento e da relação de força entre os atores sociais envolvidos, o que ajuda a explicar conquistas, retrocessos, reorganizações 138 que compõem a dinâmica social.

O mesmo se pode dizer do sindicalismo e da "eclosão" do associativismo rural na dinâmica das relações de trabalho no Brasil, principalmente a partir de meados dos anos de 1970, o que não deixa de ser um paradoxo para a ação sindical em nosso país nesta segunda década do século XXI.

\section{Iram Jácome Rodrigues}

é professor do Departamento de Economia e do Programa de Pós-Graduação em Sociologia, ambos da Universidade de São Paulo (USP) e pesquisador do CNPq.

\section{Mario Henrique Guedes Ladosky}

é professor do Departamento de Sociologia da Universidade Federal de Campina Grande (UFCG), Paraíba. 


\section{Bibliografia}

ALMEIDA, M. H. T. de. 1983. "O sindicalismo brasileiro entre a conservação e a mudança. In: SORJ, B.; ALMEIDA, M. H. T. de. (orgs.). Sociedade e política no Brasil pós-64. São Paulo: Brasiliense.

ALVES, M. H. M. 1984. Estado e oposição no Brasil (1964-1984). Petrópolis: Vozes.

BRASIL. 2006. Presidência da República. Casa Civil. Lei no 11.326, de 24 de julho. Estabelece as diretrizes para a formulação da Política Nacional da Agricultura Familiar e Empreendimentos Familiares Rurais. Disponível em: <www.planalto.gov.br/ccivil_03/_ato20042006/2006/lei/111326.htm>.

BRUMER, A. 2002. "Previdência social rural e gênero". Sociologias, Porto Alegre, ano 4, n. 7.

CARDOSO, A. 1999. Sindicatos, trabalhadores e a coqueluche neoliberal: a era Vargas acabou?. Rio de Janeiro: FGV. 2013. Ensaios de sociologia do mercado de trabalho brasileiro. Rio de Janeiro: FGV.

2014. "Sindicato no Brasil: passado, presente e futuro". In: CATTANI, A. D. (org.). Trabalho: horizonte 2021. Porto Alegre: Escritos Ed.

CASTRO, C. N. de; RESENDE, G. M.; PIRES, M. J. de S. 2014. Avaliação dos impactos regionais do Programa Nacional da Agricultura Familiar

(Pronaf). Rio de Janeiro/Brasília: Ipea (Texto para Discussão).

CONTAG - Confederação Nacional dos Trabalhadores na Agricultura.

2003. 40 anos de luta ao lado do homem e da mulher do campo. Brasília:

Contag.

CUT - Central Única dos Trabalhadores. 2013. Perfil da base sindical. São Paulo: CUT.

. Resoluções do Congresso de Fundação. 1983. Disponível em:

$<$ www.cut.org.br>.

. Resoluções do $1^{\circ}$ Congresso Nacional da CUT ( $1^{\circ}$ Concut). 1984.

Disponível em: <www.cut.org.br >.

. Resoluções do $2^{\circ}$ Congresso Nacional da CUT ( $2^{\circ}$ Concut). 1986.

Disponível em: <www.cut.org.br >.

. Resoluções do $3^{\circ}$ Congresso Nacional da CUT ( $3^{\circ}$ Concut). 1988.

Disponível em: <www.cut.org.br>.

. Resoluções do $4^{\circ}$ Congresso Nacional da CUT (4º Concut). 1991.

Disponível em: <www.cut.org.br $>$.

Resoluções do $5^{\circ}$ Congresso Nacional da CUT (5º Concut). 1994.

Disponível em: <www.cut.org.br.

Resoluções do $6^{\circ}$ Congresso Nacional da CUT (6 ${ }^{\circ}$ Concut), 1997.

Disponível em: <www.cut.org.br>. 
Resoluções do $7^{\circ}$ Congresso Nacional da CUT ( $7^{\circ}$ Concut). 2000.

Disponível em: <www.cut.org.br >.

. Resoluções do $8^{\circ}$ Congresso Nacional da CUT ( $8^{\circ}$ Concut). 2003.

Disponível em: <www.cut.org.br.

Resoluções do $9^{\circ}$ Congresso Nacional da CUT ( $9^{\circ}$ Concut). 2006.

Disponível em: <www.cut.org.br >.

Resoluções do $10^{\circ}$ Congresso Nacional da CUT (10 Concut). 2009.

Disponível em: <www.cut.org.br >.

. Resoluções do $11^{\circ}$ Congresso Nacional da CUT (11 ${ }^{\circ}$ Concut). 2012.

Disponível em: <www.cut.org.br >.

DIEESE - Departamento Intersindical de Estatística e Estudos

Socioeconômicos. 2014. "O mercado de trabalho assalariado rural brasileiro”. Estudos e Pesquisas, n. 74.

ERICKSON, K. P. 1979. Sindicalismo no processo político no Brasil. São Paulo: Brasiliense.

FAVARETO, A. 2006. "Agricultores, trabalhadores: os trinta anos do novo sindicalismo rural no Brasil”. RBCS - Revista Brasileira de Ciências Sociais, v. 21, n. 62.

FERNANDES, B. M. 2013. "A Reforma Agrária que o governo Lula fez e a que podia ser feita”. In: SADER, E. (org.). 10 anos de governos pós-neoliberais no

140 Brasil: Lula e Dilma. São Paulo: Boitempo; Rio de Janeiro: Flacso Brasil.

FIORI, M. 2009. "Contag se desfilia da CUT mas promete continuar debatendo com a central sindical”. Disponível em: $<$ http://memoria. ebc.com.br/agenciabrasil/noticia/2009-03-14/contag-se-desfilia-da-cutmas-promete-continuar-debatendo-com-central-sindical>.

FORTE, F. 2013. Os dilemas da CUT no início do século XXI: rumo a uma nova institucionalização sindical?. Tese de doutorado, Faculdade de Economia. Coimbra, Portugal: Universidade de Coimbra.

FREI BETTO. 1981. O que é Comunidade Eclesial de Base. São Paulo: Brasiliense.

HEREDIA, B.; CINTRÃO, R. 2006. "Gênero e acesso a políticas públicas no meio rural brasileiro". Revista Nera, ano 9, n. 8, pp. 1-28.

LADOSKY, M. H. G. 2009. A CUT no governo Lula: da defesa da "liberdade e autonomia” à reforma sindical inconclusa. Tese de doutorado, Faculdade de Filosofia, Letras e Ciências Humanas. São Paulo: USP.

LIMA, J. C. 2014. "Os desafios do presente e o trabalho do futuro". In: CATTANI, A. D. (org.). Trabalho: horizonte 2021. Porto Alegre: Escritos Ed. MDA - Ministério do Desenvolvimento Agrário. [Várias datas]. Programas da Secretaria da Agricultura Familiar. Disponível em: <http:/ / www. mda.gov.br/sitemda/pagina/a\%c3\%A7\%C3\%B5es-e-programas $>$. Acesso em: 30 jun. 2015. 
2014a. "Pronaf auxilia agricultores a consolidar empreendimentos”. Portal Brasil, 23 maio. Disponível em: <http:/ / www.brasil.gov.br/economia-e-emprego/2014/05/pronaf-auxiliaagricultores-a-consolidar-empreendimentos>. Acesso em: 5 nov. 2014.

. 2014b. "Recursos do Pronaf são contratados por $98 \%$ dos agricultores”. Portal Brasil, 9 jun. Disponível em: <http://www.brasil. gov.br/economia-e-emprego/2014/06/recursos-do-pronaf-saocontratados-por-98-dos-agricultores/@@nitf_custom_galleria $>$. Acesso em: 30 jun. 2015.

MEDEIROS, L. S. 2002. "Os trabalhadores do campo e desencontros nas lutas por direitos”. In: CHEVITARESE, A. O campesinato na história. Rio de Janeiro: Relume Dumará.

. 2014. "O sindicalismo rural nas últimas décadas: mudanças e permanências”. In. OLIVEIRA, R. V. de; BRIDI, M. A.; FERRAZ, M. (orgs.). O sindicalismo na era Lula: paradoxos, perspectivas e olhares. Belo Horizonte: Fino Traço.

MPS - Ministério da Previdência Social. 2014. Comprovação de Atividade Rural. Disponível em: <http://www.previdencia.gov.br/ comprovao-de-atividade-rural/>.

MTE - Ministério do Trabalho e Emprego. 2013. Dados aferição sindicalização. Brasília: MTE.

NOVAES, R. R. 1989. "Dissolver a neblina: a CUT no campo". Revista Teoria e Debate, São Paulo, n. 8.

. 1991. "Continuidades e rupturas no sindicalismo rural”. In: BOITO Jr., A. (org.). O sindicalismo brasileiro nos anos 80. São Paulo: Paz e Terra. PICHLER, W. A. 2011. "Tendências da sindicalização no Brasil: 19922009”. Indicadores Econômicos FEE, Porto Alegre, v. 38, n. 3, pp. 37-46. PICOLOTTO, E. L. 2009. “A emergência dos 'agricultores familiares' como sujeitos de direitos na trajetória do sindicalismo rural brasileiro". Mundo Agrario, La Plata, v. 9, n. 18.

2011. As mãos que alimentam a nação: agricultura familiar, sindicalismo e política. Tese de doutorado em Desenvolvimento, Agricultura e Sociedade. Rio de Janeiro: UFRJ.

. 2013. A formação da Fetraf e a situação de pluralidade sindical no campo. In: XVI CONGRESSO BRASILEIRO DE SOCIOLOGIA, $10 \mathrm{a}$ 13 de setembro 2013, Salvador, Bahia.

. 2014. "A formação de um sindicalismo de agricultores familiares no Sul do Brasil”. Sociologias, ano 16, n. 35, pp. 204-36.

RAMOS, V. 2011. "Política agrária do governo Lula valorizou o agronegócio". Entrevista com Ariovaldo Umbelino, professor titular de Geografia Agrária da Universidade de São Paulo, publicada na página 
do MST em 12 jan. 2011. Disponível em: <http://www.cartacapital.com. $\mathrm{br} /$ politica/politica-agraria-do-governo-lula-valorizou-o-agronegocio/>. RODRIGUES, I. J. 2011. Sindicalismo e política: a trajetória da CUT (19831993). 2. ed. São Paulo: LTr.

RODRIGUES, I. J.; RAMALHO, J. R. 2014. "Novas configurações do sindicalismo no Brasil? Uma análise a partir do perfil dos trabalhadores sindicalizados". Contemporânea - Revista de Sociologia da UFSCar, São Carlos, v. 4, n. 2, pp. 381-403.

RODRIGUES, L. M. 1990. CUT: os militantes e a ideologia. São Paulo: Paz e Terra.

SANTOS, W. G. dos. 1979. Cidadania e justiça: a política social na ordem brasileira. Rio de Janeiro: Campus.

SOUZA MARTINS, H. H. T. de. 1979. O Estado e a burocratização do sindicato no Brasil. São Paulo: Hucitec. 


\section{PARADOXOS DO SINDICALISMO BRASILEIRO: A CUT E OS TRABALHADORES RURAIS}

IRAM JÁCOME RODRIGUES MARIO HENRIQUE GUEDES LADOSKY

Resumo: Este artigo analisa o sindicalismo rural no Brasil, nas últimas três décadas, a partir da sua relação com a CUT e discute o crescimento significativo do associativismo rural no interior desta entidade, refletindo sobre as razões que estariam levando a maior central sindical brasileira a abrigar um contingente tão expressivo de associados do campo no conjunto de sua base sindicalizada.

Palavras-chave: Sindicalismo Brasileiro; Sindicalismo Rural; Trabalhadores Rurais; Central Única dos Trabalhadores (CUT); Taxas de Sindicalização; Agricultores Familiares.

\section{PARADOXES OF THE BRAZILIAN TRADE UNIONISM: CUT AND THE RURAL WORKERS}

Abstract: This paper analyses the rural trade unionism in Brazil on the last three decades, focusing on its relation with CUT and discusses the expressive growth of rural associativism inside CUT, reflecting on the reasons that are leading the greatest Brazilian central trade union to shelter such a large contingent of rural worker members in the set of its unionized basis.

Keywords: Brazilian Trade Unionism; Rural Trade Unionism; Rural Working Class; Central Labour Federation (CUT); Union Density; Family Farmers.

Recebido: 20/12/2014 Aprovado: 08/05/2015 